\title{
Contemporary Culture, Use, and Conservation of Sea Turtles
}

\author{
Lisa M. Campbell
}

\section{CONTENTS}

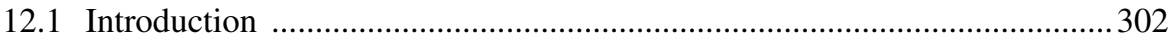

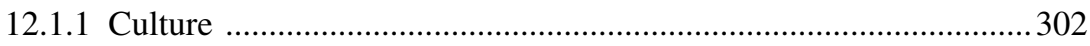

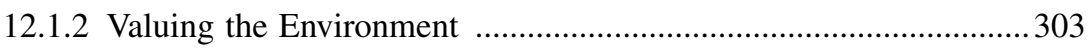

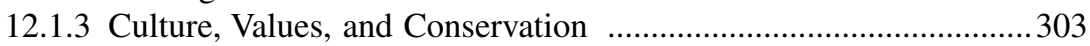

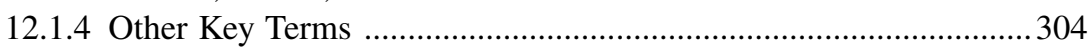

12.2 Contemporary Uses and Relations with Sea Turtles .....................................306

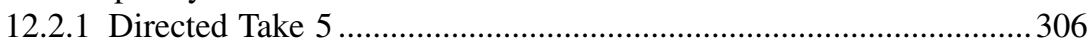

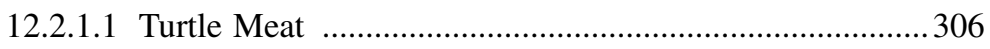

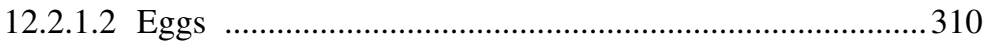

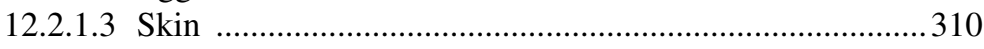

12.2.1.4 Other Parts and Products ..................................................... 311

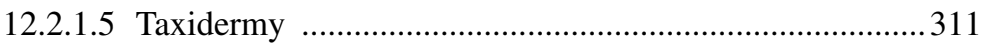

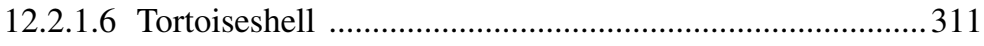

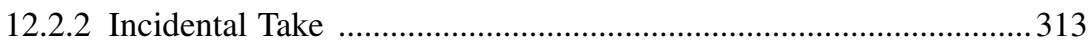

12.2.2.1 Fisheries Interactions ……………............................... 313

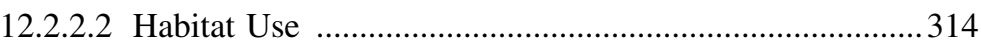

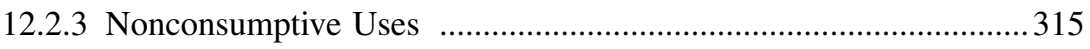

12.2.3.1 Tourism and Ecotourism …………………....................315

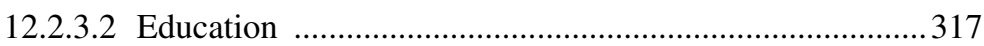

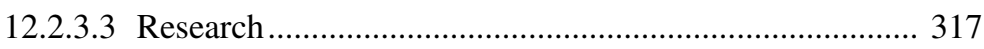

12.2.3.4 Turtles as Symbols ………………………......................317

12.3 Culture and Conservation: Cultures of Conservation ……………............319

12.3.1 Sustainable Use .........................................................................

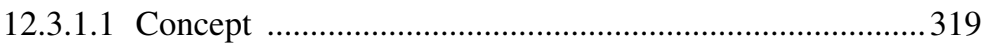

12.3.1.2 Sustainable Use and Sea Turtle Conservation ……….....320

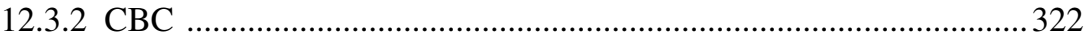

12.3.2.1 Concept .............................................................. 322

12.3.2.2 CBC and Sea Turtle Conservation ...............................322 


\subsection{INTRODUCTION}

This chapter examines contemporary links between human culture(s) and sea turtle use and conservation. It is based on two central assumptions: (1) the value and role assigned to turtles as part of nature is culturally situated, and (2) the cultural context of human relations with sea turtles is critical to the success of conservation schemes. Key concepts and terms used are discussed in this introduction. Section 12.2 highlights various types and examples of sea turtle use and their cultural significance. In Section 12.3, the link between culture and conservation policy, and specifically, two contemporary conservation concepts - sustainable use and community-based conservation $(\mathrm{CBC})$ - are discussed.

\subsubsection{Culture}

Williams (1981) describes two main senses of culture. Culture is "a distinct 'whole way of life', within which, now, a distinctive 'signifying system' is seen not only as essential but as essentially involved in all forms of social activity." Culture in this sense mediates how we understand and make sense of the world around us. The more common sense of culture is "artistic and intellectual activity" and resulting products. The two senses converge, in that the former whole way of life incorporates the central interests and values of a people (Williams, 1981), and these are often manifested in products of material cultural. Thus, sea turtles may be part of the whole way of life, and this may be reflected in art, crafts, or music.

Culture operates on a number of levels, and these levels interact (Seppälä and Vainio-Mattila, 1998). Although Western culture is a broad and encompassing term, subcultures (for example, corporate culture, culture tied to ethnic identity, and counterculture) can exist within and sometimes challenge dominant Western culture. Power is an issue in determining which cultures dominate, and domination by one culture implies subjugation of others. Culture is dynamic and in a constant state of change; change does not mean that people become cultureless, or that their cultures become meaningless.

There is a growing body of literature addressing cultural (and social) constructions of nature (Braun and Castree, 1998; Ellen and Fukui, 1996; Escobar, 1999). Via culture, society determines what constitutes nature and what role nature plays in cultural and social life. Via culture, priorities are set for conservation and development. As cultures differ across time and space, different cultures will place different priorities on the individual components of nature, and in some cultures, the concept of nature as something separate from humans does not exist. In wildlife conservation, culture is used to explain particular sets of human relations with various species (e.g., Nietschmann $[1973 ; 1979]$ explained the cultural value of sea turtles to the Miskito Indians of Nicaragua; see Section 12.2.1.1). 
In a conservation context, there are often two extreme positions on culture. For some, culture is sacred, something to be respected and revered, and deserving of conservation in its own right (e.g., Cultural Survival International, http://www.culturalsurvival.org/), especially if it is indigenous. For others, culture is a red herring raised to deter conservation efforts, the claims of which need to be thoroughly interrogated (Campbell, 2000). Culture is often most obvious when it is someone else's (Seppälä and Vainio-Mattila, 1998). Although a North American observer might see a Central American peoples' desire to consume turtle eggs as cultural, the same North Americans are less likely to explain their own desire to protect turtle eggs in the same way. Rather, protection is taken for granted as the desirable and correct outcome. Thus, rather than try to understand cultural meanings associated with sea turtles, force is sometimes used to make them do what we would, or education is used to get them to agree with $u s$. These approaches underestimate the importance of cultural norms, and they can fall short of their long-term conservation goals as a result.

\subsubsection{Valuing the Environment}

As William's definition of culture implies, values are intricately related to and embedded in culture. Humans value the environment and wildlife in a variety of ways: for economic, recreational, scientific, aesthetic, historic, and philosophic or spiritual reasons (Rolston, 1994). Environmental values vary from place to place and, within a particular place, different environmental values can coexist (e.g., Kempton et al., 1995). Sea turtles are valued in different ways by different people, and because of their international migrations that take them across geographic, political, and cultural boundaries, conflicts in values frequently can arise.

\subsubsection{Culture, Values, and Conservation}

If definitions of nature and environmental values are embedded in culture, then so too is conservation. For example, Western conservation has traditionally been pursued via the creation of parks and protected areas, and the National Park model that emerged in the U.S. in the late 1800s reflects the culture of the time. National Parks are physically delineated, the state is responsible for their creation and maintenance, and only certain nonextractive human activities are sanctioned within their borders. These features reflect the cultural beliefs that humans are separate from (and often above) nature, the state is responsible for and capable of protecting the public good, and nature can be contained in physically delineated areas. Key in the park movement were the U.S. "romantics," (primarily) men who reacted against the frontier mentality that characterized the settlement of the American west. The frontier mentality saw nature as dangerous and threatening, something to be tamed for productive purposes. The romantics saw nature as a purifier of the tarnished modern soul, and needing protection (McCormick, 1989). Both opposing visions of nature were linked to the dominant culture of U.S. expansion and ideas of progress.

Over the last 20+ years, there has been a shift away from a traditional protected areas approach toward an attempt to reconcile conservation with development needs, 
as reflected in the current definition of conservation adopted by the World Conservation Union (IUCN). Conservation is "...the management of human use of organisms or ecosystems to ensure such use is sustainable. Besides sustainable use, conservation includes protection, maintenance, rehabilitation, restoration, and enhancement of populations and ecosystems" (IUCN, 1980).

This shift arose as a number of shortcomings with protected areas became evident, particularly when applied outside of their cultural context in developing countries. The vision of humans as separate from nature, for example, can conflict with local visions of human-environment relations (Ghimire and Pimbert, 1997), and can undermine cultural norms and traditional or indigenous knowledge (Marks, 1984). The resulting cultural mismatch can sabotage conservation efforts; if local people do not support a conservation undertaking, encroachment and illegal harvesting activities may result. Two responses to the problems experienced with transferring protected areas to developing countries are sustainable use and $\mathrm{CBC}$, and these are discussed in Section 12.3.

\subsubsection{Other Key Terms}

Other key terms in the discussion of culture and conservation are community, indigenous, traditional, and subsistence - terms that are often used to delimit sea turtle use. For example, a sea turtle egg-collecting project might be justified as a traditional activity of indigenous people undertaken for subsistence purposes. Such terms are rarely defined, and are thus problematic.

Community defines both actual social groups (i.e., the people of a district) and the quality of relations among people (i.e., holding something in common, or a sense of common interests or identity) (Williams, 1983). Community is also used to distinguish the more direct and total relations between people from the more formal, abstract, and instrumental relations of people with the state. "Community can be the warmly persuasive word to describe an existing set of relationships" (Williams, 1983) and is rarely used in a negative sense.

Communities are increasingly seen as critical to the success of conservation efforts, but there are difficulties associated with defining communities that may arise from the term's dual meaning. The people of a district may be assumed to equal the relations among people, and in conservation practice, communities are often treated as self-evident or generic, and homogenous (Brosius et al., 1998; Leach et al., 1997; Wells and Brandon, 1992; Western and Wright, 1994). Communities are also assumed to share culture and related values of the environment. This is not always the case, and a clear sense of who and what the community is will be critical for conservation success at the local level.

Indigenous is defined as something "originating or occurring naturally in the place or country specified" (Avis, 1980). The cultural claims of indigenous peoples to use wildlife are often given greater weight than those of nonindigenous people. For example, Donnelly (1994) describes sustainable use of sea turtles as “...designed to promote controlled and renewable use of wildlife for the benefit of indigenous people and endangered species." Emphasis on indigenous assumes that use of sea turtles by indigenous peoples has different impacts than use by nonindigenous
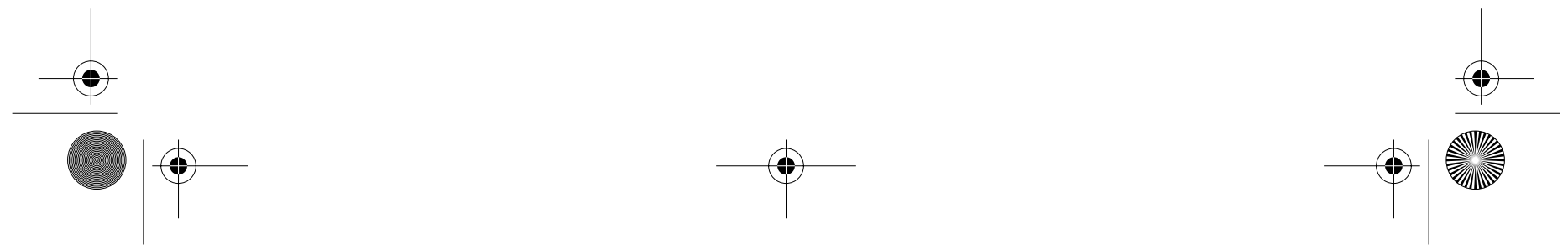
peoples, and that indigenous peoples have stronger cultural biases toward use, which may not always be the case.

Tradition refers to handing down knowledge, or passing on a doctrine, from one generation to another. Often, tradition is associated with a sense of ceremony, duty, and respect. The process by which certain elements of knowledge are passed down, whereas others are not, shows that traditions are selective (Williams, 1983). Like the term indigenous, tradition is used to explain or justify certain cultural practices. When evaluating traditional claims to resources use, some people claim that, to be traditional, an activity cannot have changed over time; for example, fishing for turtles with an outboard motor cannot be traditional when it was originally done using a dugout canoe (see Campbell, 2000). This interpretation of tradition focuses on the means for achieving, rather than the meaning of a tradition. Furthermore, it implies stasis that has never existed in human history. The addition of an outboard motor to a canoe, for example, is an incremental step in the evolution of technology, rather than a leap from traditional to nontraditional. Improved technologies do not always lead to increased resource exploitation (Lyver and Moller, 1999), and Berkes et al. (2000) warn against associating tradition with stasis.

Tradition has become more important in conservation because of the increasing popularity of traditional ecological knowledge (TEK). Studies of ecological change over time have sometimes challenged Western scientists' interpretations of environmental change and revealed the logic of indigenous or traditional management practices (Berkes et al., 2000; Leach and Mearns, 1996; Nader, 1996), and Miller (2000) discusses the links between traditional and nontraditional knowledge of marine turtles. The existence of TEK in communities does not equate automatically with desire or willingness to conserve, but there is nevertheless a need to recognize it.

Subsistence economies are those that extract the basis of existence from the natural environment, and that focus on satisfaction of existing food needs rather than on accumulation of surplus (Nietschmann, 1973). Such regimes existed prior to, or exist external to, the market economy, and are by and large devalued and destroyed by it (Escobar, 1992). With the widespread introduction of market economies throughout the world, few fully subsistence regimes exist, and the term has been "implicitly redefined as the individual producer's socio-biological survival under conditions of accumulation of capital" (Robert, 1992).

In a conservation context, depletion of sea turtles (and other species) is often blamed on the transition from a subsistence to market economy (e.g., Nietschmann, 1979; Spring, 1995; see also Section 12.2.1.1). Although such transitions have adverse environmental and cultural impacts, the reemergence of true subsistence economies is unlikely. Nonsubsistence use does not by definition imply large scale, uncontrolled use, only that capital accumulation might result.

Discussions of culture and conservation are often restricted to "other" cultures that, in opposition to dominant Western culture, might be community based, subsistence, traditional, or indigenous. Although it is important to understand such terms, this narrow focus depicts culture as influencing conservation somewhere else. In the following examination of culture and sea turtle use and conservation, evidence from both other cultures and Western culture is included. Culture informs how all readers make sense of their worlds, including the world of sea turtle conservation. 


\subsection{CONTEMPORARY USES AND RELATIONS WITH SEA TURTLES}

Consumptive use of sea turtles around the world has been documented recently (Thorbjarnarson et al., 2000a). Although some of the facts of use are repeated and expanded on here, the focus is on the links between culture and use, and on various kinds of use, including nonconsumptive. Thorbjarnarson et al. (2000a) consider some culture contexts of use. For example, they discuss the impacts of different religions on consumption. The listing of cultural influences on turtle use (Thorbjarnarson et al., 2000a), however, reflects the point made in Section 12.1.1: It is often easiest to see the influences of other cultures. Meanwhile, Western culture has impacted on contemporary use of sea turtles in two profound, and seemingly opposite, ways. First, the expansion of Western capitalism has shaped sea turtle consumption; economies that might previously have used turtles for subsistence purposes now have cash needs that may be met through selling sea turtles and their by-products. Second, the separation of humans from nature in Western culture, and the veneration of "charismatic megafauna," have created a demand in the West for the complete protection of sea turtles and their relegation to tourist spectacle. Some of these issues are discussed in more detail below.

\subsubsection{Directed TAKe}

\subsubsection{Turtle Meat}

The list of countries using sea turtles for meat (Thorbjarnarson et al., 2000a) includes the U.S. (Florida, Georgia, Louisiana, Mississippi, North Carolina, Texas, and Virginia), the Atlantic coast of Central America, Ecuador, Peru, Madagascar, Seychelles, India, Sri Lanka, Japan (fishing in other waters), Indonesia, Australia, Torres Straights, and Papua New Guinea. To this list can be added Bangladesh (Islam, 2001), Thailand (Aureggi et al., 1999), Liberia (Siakor et al., 2000), Egypt (Venizelos and Nada, 2000), equatorial Guinea (Tomás et al., 1999), Guinea-Bissau (Fortes et al., 1998), Cuba (Carrillo et al., 1999), Nicaragua (Nietschmann, 1973; 1979; Lagueux, 1998), Costa Rica (Opay, 1998), Belize (Frazier, in press), Mexico (Nichols et al., 2000), and several Caribbean islands (Antigua and Barbuda, Bahamas, British Virgin Islands, Cayman Islands, Grenada, Haiti, Saint Kitts and Nevis, Trinidad and Tobago, and Turks and Caicos [Frazier, in press]). In some of these countries, use is illegal, but nevertheless continues (e.g., even in the U.S., illegal use occurs [Addison, 1995]).

Most accounts of sea turtle use are without reference to why turtles are used and what use means (beyond economic profit). There have been some studies of the cultural importance of sea turtles to communities, however, and some of these are described briefly here.

\subsection{Nicaragua}

The role that turtles play in the culture of the Miskito Indians of Nicaragua was made famous by Nietschmann $(1973 ; 1979)$. At the time of Nietschmann's studies, a Miskito fisherman's ability to share green turtle meat among kin and friends was 
a critical component of social relations: "Meat shared in this way satisfied mutual obligations and responsibilities and smoothed out daily and seasonal differences in the acquisition of animal protein" (Nietschmann, 1979). These social relations took place in a wider cultural context, in which sea turtles were the Miskito's most important resource.

In later writings, Nietschmann (1979) described the impacts of the introduction of commercial turtling. As turtles gained cash value, people spent more time turtling, and the more time thus spent, the less time spent on other subsistence activities, and the greater the need for cash. With the introduction of nets (supplied by the manufacturers of turtle products), the traditions of fishing changed; nets made everyone fishermen, and the importance of skills as a striker diminished. As more people became turtlers, fewer turtles were easily captured and more time and effort had to be spent turtling.

The introduction of a cash value for turtles also created tension in the community. The need to sell turtles for cash in order to purchase goods meant that fishermen felt unable to fulfill their meat-sharing obligations. This was especially true in times of harvest scarcity. Nietschmann (1979) concludes that the introduction of a market economy contributed to both the reduction of the resource and the economic and cultural impoverishment of the community. Miskito Indians continue to take turtles; Lagueux (1998) estimates that 10,000 turtles are taken annually. However, the tradition of meat sharing has disappeared (C. Lagueux, personal communication, 2002).

\subsection{Costa Rica}

The importance of green turtles to the human community at Tortuguero, Costa Rica, has shifted over the years. The name Tortuguero (and sometimes Turtle Bogue) means turtle place, and Rudloe (1979) describes the link between Cerro Tortuguero (a hill at the mouth of the Tortuguero river) and the legend of the turtle mother, a rock believed to attract turtles to nest. Although humans settled at Tortuguero in the 1930s, turtles have long been fished there; the Miskito Indians fished offshore for hundreds of years prior to Tortuguero's settlement, and European explorers restocked food supplies with Tortuguero turtles as early as the seventeenth century (Lefever, 1992). Until the 1970s, residents of Tortuguero captured green turtles for consumption; cooking methods for green turtle meat and eggs have been described (Rudloe, 1979; Lefever, 1992). Residents and nonresidents also captured turtles onshore for sale to boats waiting offshore. Although commercial turtling was on the wane in the 1960s (Parsons, 1962), turtles remained an important local resource, especially because other enterprises in the region (a banana plantation and a sawmill) experienced boom and bust cycles. In an isolated rainforest with limited agricultural potential, turtles provided a dependable and free source of protein during the bust cycle. When conservation efforts began in the 1960s and 1970s, turtle exploitation was prohibited with one exception: the community is theoretically allowed to slaughter one turtle a week (three according to Lefever [1992] and two according to Rudloe [1979]) for communal distribution. However, the criteria to be met for such harvest are stringent to the extent that this practice has stopped (S. Troeng, personal communication, 2000), although some long-time residents of
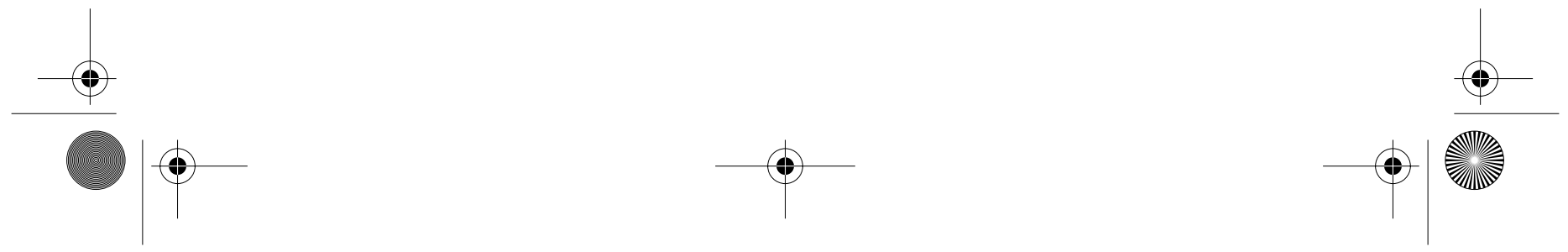
Tortuguero would like to be able to eat turtle meat (Peskin, 2002). The role of turtles in the culture of Tortuguero continues to evolve with the growth of ecotourism (see Section 12.2.3.1).

In the Caribbean port city and provincial capital of Limon, Costa Rica, a sea turtle fishery that licensed the capture of 1800 green turtles a year operated until 1999, when environmentalists in Costa Rica and the U.S. challenged the constitutional legitimacy of the harvest and won (Taft, 1999). The "cultural basis for eating turtle" (Opay, 1998) in this area is recognized and, prior to the challenge, several Costa Rican biologists described the fishery as "justified" for cultural reasons (Campbell, 1997). The petition against the harvest illustrates how values within a country can clash. The conservation values held by the Costa Ricans petitioning against the harvest were given precedence over the cultural and economic values of turtles to Limon fishermen.

\subsection{Mexico}

The Seri (or Comcaac) of the Sonoran coast and islands of the Gulf of California are "one of the last indigenous cultures in North America able to withstand total integration into local European derived cultures" (Nabhan et al., 1999). Cultural links between Seri culture and sea turtles are evident; turtles are not just food, but "the symbolic foundation of their marine resource based culture" (Nabhan et al., 1999). The importance of sea turtles manifests in material culture, including songs and legends. With the introduction of laws preventing harvesting, the Seri have had to restructure their use of marine resources. They now focus on other fishing and supplement their livelihoods with products from "adjacent Mexican culture." The traditions of sea turtle harvesting are no longer passed on, and Nabhan et al. (1999) point out that when elders pass on "we can assume much information will be lost."

\subsection{Venezuela}

For the Wayuu of Venezuela, sea turtles are related to fertility, and consuming meat and blood affects "masculine vitality." Dreaming of turtles is also related to sexual activity and turtle craniums are often hung in fruit trees to encourage growth (Parra et al., 2000). Parra et al. (2000) identify the need to understand these beliefs, so that educational strategies to show people the "real valuation" of the resource can be designed.

\subsection{Indonesia}

Suarez and Starbird (1996) examined the cultural context of leatherback hunting by people living in the Kei Islands of Indonesia. They describe the traditions, rituals, and beliefs (known as adat) that guide the turtle hunt. Hunts are highly ritualized and, under adat, meat is used for subsistence purposes and cannot be sold. As population pressures grow and other subsistence resources are depleted, increased fishing for subsistence rather than ritual purposes has resulted. Suarez and Starbird (1996) believe increased fishing could be a sign of cultural erosion, and suggest provision of alternative sources of protein to reduce the need for subsistence leatherback fishing. 


\subsection{Papua New Guinea}

Spring (1995) describes the cultural importance of turtles in Papua New Guinea, manifested in various products of material culture, including bride price items made from shell, oral histories, and legends. Cultural rituals and traditions vary across the islands and some contribute to conservation, while others do not. For example, in some clans, permission to hunt turtles must be sought from traditional authorities, and turtles are used only for feasts, both traditional and nontraditional. Traditional hunting techniques used by some clans limit the number of turtles caught. Certain clans who believe themselves descended from turtles do not eat turtles. In contrast, in one village with a strong cultural attachment to leatherbacks, every nesting female found is slaughtered. Spring (1995) expresses some concern that traditional authority is eroding, historically because of some colonial laws and practices, and more contemporarily among younger generations influenced by Western culture and in areas closer to urban centers. In more remote regions, traditions remain stronger.

\subsection{The Caroline Islands}

The cultural importance of turtle hunting by people in the Caroline Islands is described by McCoy (1995): "The turtles contribute much to their overall cultural stability, reinforcing their independence from the outside. The estimated maximum contribution to the protein, ... is not nearly as important as this cultural role." The tradition of travel by dugout canoe, a subsistence economy, and taboos and ceremonies that surround the hunt historically provided a buffer on the number of turtles taken. However, the introduction of a cash economy, government settlement programs that spread turtle fishing skills among islanders, and the erosion of traditional taboos, have lead to increased pressure on turtles. As part of their maritime culture, local people see turtles as part of the sea, the "provider for all things," and thus show little concern at evidence of decreasing populations. McCoy (1995) argues for conservation programs to be undertaken with the people of the area firmly in mind.

\subsection{Australia}

In February 2002, the Australian Broadcasting Corporation (ABC) posted a recipe for green turtle on its website, as part of an aboriginal television program that discussed traditional diets. The resulting debate that erupted on CTURTLE, an online discussion group, addressed many issues, including the ethics of the ABC in posting a recipe based on an endangered species, the rights of aboriginal people to hunt such species, and the legitimacy of claims to traditional culture (messages archived at www.lists.ufl.edu/archives/cturtle.html). The debate reflects some of the difficulties in dealing with issues of culture and use.

In Australia, aboriginal peoples are allowed to use sea turtles for noncommercial purposes. Kowarsky (1995) found that the cultural basis of sea turtle use varies between different groups and that, overall, the integration of aboriginals into modern Australian reduced the number of turtles hunted. This finding contrasts with other examples, where integration into Western economies led to increased exploitation. In Australia, it may be the rejection of modernization by aboriginal people and their return to traditional territories and lifestyles that ultimately increases turtle hunting (Kowarsky, 1995). 


\subsubsection{Eggs}

The list of countries using sea turtles eggs (Thorbjarnarson et al., 2000a), both legally and illegally, includes countries on the Atlantic coast of Central America, Mexico, Iran, Saudi Arabia, India, Thailand, Malaysia, Indonesia, Philippines, and Papua New Guinea. Countries that can be added to this list include: Suriname (Mohadin, 2000), Costa Rica (Campbell, 1998), Guatemala (Juarez and Muccio, 1997), Panama (Evans and Vargas, 1998), Honduras (Lagueux, 1991), Nicaragua (Ruiz, 1994), Bangladesh (Islam, 2001), and Myanmar (Thorbjarnarson et al., 2000b).

There are few studies of egg use, and these have focused primarily on economic value and how use is regulated (e.g., Lagueux, 1991; Campbell, 1998). A common cultural reference is to beliefs about the aphrodisiac qualities of eggs, particularly in Central America. In Ostional, Costa Rica, however, Campbell (1997) found that, although people recognized the aphrodisiac reputation of eggs, they emphasized their nutritional and economic value to families. Women in particular dismissed the aphrodisiac claim. Lefever (1992) also found aphrodisiac doubters in Tortuguero, although Rudloe (1979) credits the claim based on his own experience. In Guatemala, Juarez and Muccio (1997) suggest eggs are used for aphrodisiacal purposes, and as such are "not a basic need." However, the authors state that one nest of eggs earns an agricultural or farm laborer the equivalent of one fourth of a month's salary, suggesting significant importance. Eggs clearly fill an economic need, and culture and economy are not so easily separated.

\subsection{Costa Rica}

The legal, commercial egg collection project at Ostional, Costa Rica, is the bestknown example of egg use (Cornelius et al., 1991; Campbell, 1998; Thorbjarnarson et al., 2000a). The economic value of this resource is well recognized in the community: $70 \%$ of households rely on the egg collection as their primary source of income (Campbell, 1998). However, Campbell's (1997) study of the egg project illustrates the subtle ways in which turtles play a part in culture. First, life in Ostional is organized around sea turtle nesting, and the work of the community cooperative extends beyond the egg project; for example, it implements village development activities. Second, the project has contributed to a sense of independence and pride in the community, and to a level of organization unseen in many comparable coastal villages (March, 1992). Third, the "sense of the world" meaning of culture is translating into material culture. Residents tell stories about the turtles, discuss in detail when they will arrive, and take pride in activities they do to protect hatchlings. There are several turtle carvers and one poet, even though the latter is not part of the egg-collecting cooperative. Fourth, many residents see themselves as lucky to have the turtles, whose presence on the beach is in the hands of God (Campbell, 1997). Turtles are thus intertwined in daily life and undoubtedly contribute to residents' understandings of their world.

\subsubsection{Skin}

The skin of olive ridley turtles has been used to fashion leather accessories. Turtle leather has been manufactured in Mexico and Ecuador, and leather products have
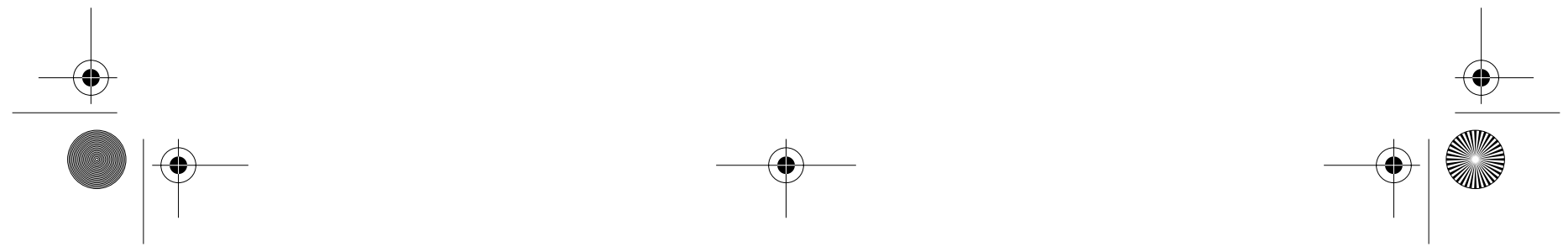
been imported by Japan, France, Spain, Italy, and the U.S. (Thorbjarnarson et al., 2000a). The use of animal parts in fashion has a long tradition. In Victorian England, women decorated their hats with bird feathers, a trend that threatened some bird populations (McCormick, 1989). The use of animal fur in fashion has become highly politicized in the West, but fur continues to find a place in fashion (Anonymous, 2001). Any cultural significance of sea turtle leather accessories in fashion is undocumented.

\subsubsection{Other Parts and Products}

As reported in Thorbjardarson et al. (2000a), oil from turtles has been used to cure wooden boats in the Persian Gulf (Ross and Barwani, 1982) and in India (Kar and Bhaskar, 1982). Turtle penis is used as an aphrodisiac on the Red Sea coast of Saudi Arabia (Miller, 1989), and turtle blood is used to treat ailments in India (Silas and Rajagopalan, 1984). In Togo, various parts of turtles are used for medicinal purposes (Hoinsoude et al., in press). The prevalence of wild animal parts in traditional medicine is a topic that concerns conservationists (Roberts et al., 1999). However, studies on cultural significance of, or attachment to, such remedies are lacking.

\subsubsection{Taxidermy}

Animal collection and taxidermy has had its place in Western culture. McCormick (1989) describes collectors in Victorian England, and how their amateur enthusiasm contributed to depletion of populations. The popularity of collecting reflected enthusiasm for science and particularly natural history. Turtle enthusiasts have also been collectors. In The Windward Road (Carr, 1967), Carr celebrates when a rare species of tortoise is captured and killed so that it can be added to his collection.

Taxidermy continues to serve the tourist trade: " 'stuffed' turtle curios from Southeast Asia" have been available in Hawaii (Balazs, 1977). More recent reports of "whole, stuffed turtles and tortoiseshell products" in Vietnam (Thuoc et al., 2001), of subadult hawksbills in Bangladesh (Islam, 2001), and of turtle heads and carapaces in Uruguay (Lopez and Fallabrino, 2001) identify tourists as the target market. What drives current collection is unknown. Tourists purchasing such items risk fines if traveling to or from a Convention on International Trade in Endangered Species of Wild Fauna and Flora (CITES) signatory country, although some may be unaware of such risk.

\subsubsection{Tortoiseshell}

Tortoiseshell, traditionally obtained from the hawksbill turtle, has ranked among the world's luxury goods since earliest recorded times (Anonymous, 1977). Anthropologist Elizabeth Overton identified tourists purchasing hawksbill shell in the Maldives as contributing to "wiping out sea turtles" (Anonymous, 1977). Balazs (1977) included hawksbill shell on his list of items available in Hawaii. The World Society for the Protection of Animals (no date) reported that in a 12-month period, 
tortoiseshell was available to tourists in Barbados, Belize, Costa Rica, Cuba, Dominican Republic, Fiji, Indonesia, Japan, Maldives, Mexico, Nicaragua, São Tomé, Sri Lanka, Thailand, and Vietnam (Figure 12.1). As with stuffed turtles, tourists risk fines in violation of CITES if caught transporting turtle shell between CITES signatory countries. Mortimer (1977) gives anecdotal evidence that tourists may be apprised of such risks while simultaneously being encouraged to buy. Shell also has cultural importance for communities. Three cases of hawksbill shell use are described in further detail.

\subsection{Japan}

Japan has a long history of crafting hawksbill shell (bekko) into various decorative items, some of which that have been found in ruins of a seventh century city. Bekko is crafted using traditional techniques and tools thought to be the same as those used 300-1000 years ago. Families pass on skills from one generation to the next, and one of the oldest bekko families (Ezaki in Nagasaki) is traced to 1709 (Kaneko and Yamaoka, 1999). The popularity of bekko crafting in Japan depends on the status of trade relations, because hawksbill shell has to be imported, and the bekko industry is currently in decline because of trade restrictions. Although Japan formerly invoked an exception to CITES to import hawksbill shell, it withdrew this in 1994 under pressure from the U.S. The Japanese Bekko Association currently estimates that it would require 4 tons of hawksbill shell (compared to 20-30 tons imported in the 1980s) to allow the remaining family-owned bekko companies to continue to operate (Kaneko and Yamaoka, 1999). Japan's desire to import hawksbill has been at the center of two controversial Cuban proposals to CITES that would allow for limited trade in shell between the two countries (Campbell, in press b; Mrosovsky, 2000; Richardson, 2000).

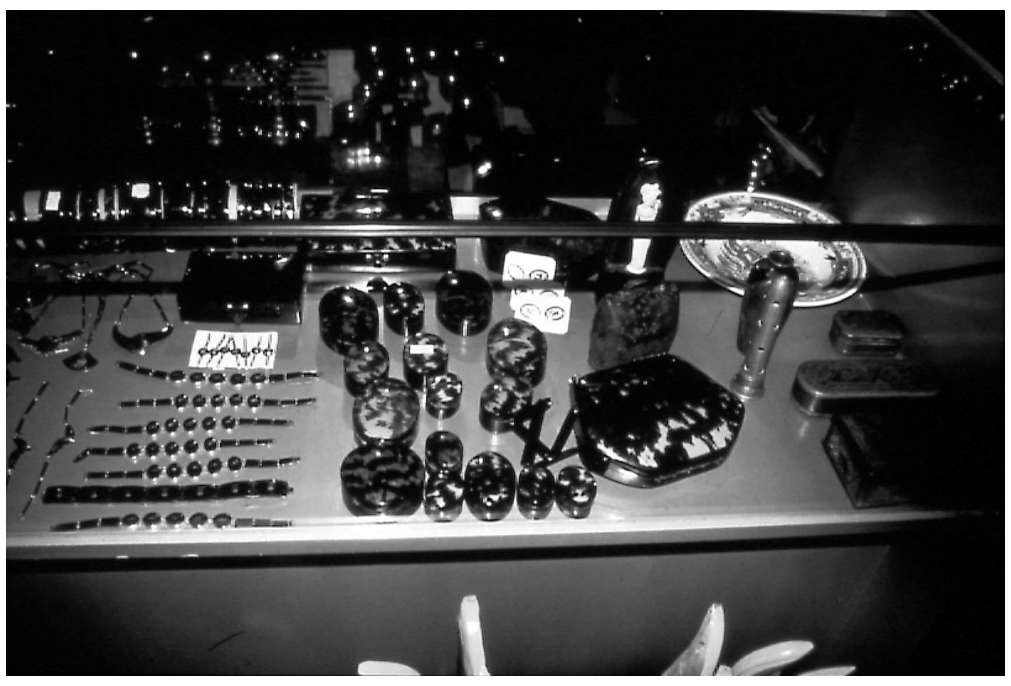

FIGURE 12.1 Turtle shell products displayed in a souvenir shop, illustrating turtles as product. (From World Society for the Protection of Animals (WSPA). With permission.) 


\subsection{Seychelles}

"The people of Seychelles view turtles as an integral part of their culture and economy" (Mortimer and Collie, 1998). Hawksbill shell has been used for more than 200 years, exported to Europe and more recently Japan, and fashioned locally into items for sale to tourists. This ended in the late 1990s, when the government of Seychelles banned commercial trade in hawksbill products and slaughter within territorial waters. Artisans were compensated and sold their stockpiles to the government. Stockpiled shell was burned publicly in 1998.

At the Nineteenth Annual Symposium on Sea Turtle Biology and Conservation, a resolution was passed acknowledging "that by destroying its stockpile of raw hawksbill shell the Government of Seychelles made a statement to its citizens and to the world that it recognizes the beauty of the natural environment of Seychelles, of which healthy populations of free-living sea turtles are an inherent component..." (Plotkin, 1999). Not all sea turtle conservationists agreed with this position, as seen in an exchange on CTURTLE. Some people criticized the burning as a political gesture that did little to improve the fate of live hawksbills, or as wasteful; income earned via sale of the shell could be used to compensate out-of-work artisans and to pay for conservation activities. The diversity of values and beliefs about conservation was highlighted in the exchange and, like many discussions of conservation taking place in internationalized cyberspace, the voices of local people were absent.

\subsection{Palau}

In Palau, the large costal hawksbill scutes are molded into polished bowls called toluk and used as an exchange valuable among women. This form of traditional money is circulated exclusively by Palauan women to give gratitude for services and courtesies offered among their families (Smith, 1983). The specific value of toluk is dependent on its aesthetic and historical characteristics, and is influenced by the changing economy of toluk circulation. Direct harvest of hawksbill turtles for toluk and the production of jewelry, mostly for sale to tourists, has lead to continual pressure on local populations. In recognition of the marked declines in nesting and foraging turtles, the Palau women's association, Didil Belau, recently called for a 20-year moratorium on hawksbill harvesting (P.K. Mad and M.D. Guilbeaux, personal communication, 2002).

\subsubsection{InCIDENTAL TAKE}

\subsubsection{Fisheries Interactions}

Although turtle drownings in shrimp trawls have long been a concern to sea turtle biologists (Carr highlighted the impacts of shrimping on Kemp's ridleys in 1977 [Carr, 1977]), other types of fishing activities, for example longline and drift net, are of increasing concern. The link between culture and such an indirect use of sea turtles may seem tenuous. However, one of the best-known cases of fisheries interaction with sea turtles, i.e., via shrimping, and the debates about how to solve the bycatch problem via turtle excluder devices (TEDs), provides an example that can be examined through the lens of culture in three ways. 
First, in an effort to reduce turtle drownings in shrimp trawls, use of TEDs was made mandatory under U.S. law in 1989, after 10 years of failed attempts to encourage voluntary use (Crouse, 1999; Margavio and Forsyth, 1996). Shrimpers resisted the legislation, claiming TEDs result in reduced catch and arguing that they should be compensated for property loss (Anonymous, 1995). However, resistance was more than economic. In their book, Caught in the Net, Margavio and Forsyth (1996) explore the cultural context of the TEDs conflict. For example, they describe traditional Cajun culture, its roots in fishing and hunting, and its emphasis on family, and the role shrimping plays in supporting this. Resistance to TEDs was based on a desire to protect this culture. Resistance was also to regulation in general, the marginalization of shrimping in the face of other economic activities, and erosion of independence.

Second, TEDs can be described as the technocratic solution to the turtle drowning problem, and were designed as "an effective way to allow shrimping to proceed virtually unimpeded while protecting most sea turtles from drowning in trawls" (Crouse, 1999). Thus, TEDs are part of a solution that does not address the overcapitalization of the shrimp and other commercial fishing industries, and is firmly imbedded in late-stage capitalism, a defining characteristic of Western culture.

Third, when U.S. shrimpers and environmentalists appealed to the U.S. government to expand the TEDs requirement to shrimp imports (which it did under Section 609 Public Law 101-162), several Asian countries brought a dispute to the World Trade Organization (WTO). Even Thailand, a country that uses TEDs and would not have been embargoed, joined the dispute on principle. As Crouse (1999) points out, several issues were at stake in the dispute: sovereignty and rights to dictate fishing policy in territorial waters, rights of developed countries to dictate environmental policy in developing countries, rights of the U.S. to restrict access to its domestic market in the era of free trade, and obligations of a global trade system to protect endangered species. Values clearly play a role in this debate, and the prioritization of issues by individual countries reflects cultural biases and their coexistence in a global system (sea turtles have played a more general role in antiglobalization protests, as discussed in Section 12.2.3.4).

\subsubsection{Habitat Use}

In the mid-1990s, a conflict erupted in Volusia County, FL, and involved environmentalists, recreational drivers using a 28-mile stretch of sea turtle nesting beach, and county government officials. Because of impacts of beach driving and artificial lighting, environmentalists launched a lawsuit against the county for violation of the Endangered Species Act (ESA). The county responded by devising a management plan with the objective of obtaining a permit to "take" sea turtles and eggs (indirectly) under the ESA, and argued that beach driving constituted a cultural asset (Fletemeyer, 1996). Other issues that arose included the rights of people to hold local government accountable for actions impacting endangered species, and the tenth amendment of the U.S. Constitution that prevents the federal government from compelling states or localities to implement national programs. Two legal think tanks with little stake in the turtle conservation outcome became involved in the dispute to argue for

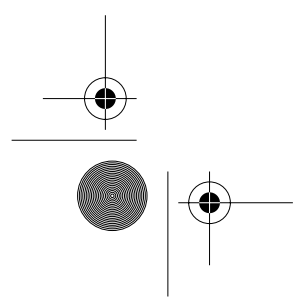


upholding the tenth amendment (Kostyack, 1999), and this demonstrates how conservation conflicts are often about more than conservation. Although Fletemeyer (1996) might dismiss cultural claims to beach driving as euphemistic, there are clearly several cultural issues at stake in this conflict.

More generally, development of sea turtle nesting beaches for private homes, industry, and tourism infrastructure has been a highly contentious issue in the southern U.S., particularly in Florida. The development itself, and subsequent efforts to protect the investment against damage, constitutes an indirect use of sea turtles through alternation and sometimes elimination of nesting habitat. Beliefs about private property, free market development, and the role of government regulation, all central components of contemporary Western culture, drive this competition.

\subsubsection{NonCONSUMPtiVE USES}

\subsubsection{Tourism and Ecotourism}

Tourists interact with turtles in the U.S. (Balazs, 1995; Johnson et al., 1996), Honduras (Dempsey, 1996), Costa Rica (Campbell, 1999; Campbell, in press a; Gutic, 1994), Brazil (Marcovaldi and Marcovaldi, 1999), Trinidad and Tobago (Fournillier, 1994), Greece (Dimopoulos, 2001), Turkey (Yerli and Canbolat, 1998), Taiwan (Cheng, 1995), and Australia (Wilson and Tisdell, 2001). There are also many relatively undocumented instances of tourist-turtle interactions.

The impacts of tourism on turtles include tourists purchasing souvenirs made from turtle products (Section 12.2.1.6), loss of habitat through resort development, competition for use of beach with tourists and infrastructure (chairs, umbrellas), direct interference with turtles by tourists (taking pictures, sitting on turtles), turtle strikes by motorized water vehicles, hatchling disorientation by development lighting, and hatchling trampling by tourists on beaches at night (World Society for the Protection of Animals, 1997). Many of the locations listed above have experienced some if not all of these problems. Conflicts have erupted in some locales (i.e., Zakynthos, Greece) where the tourism industry and tourists themselves value coastal resources differently than do turtle conservationists.

Ecotourism is an alternative form of tourism, defined as "responsible travel to natural areas that conserves the environment and sustains the well-being of local people." (Ecotourism Society, no date). Ecotourism is often promoted as nonconsumptive use of wildlife, and a means of reconciling conservation with economic development, particularly in developing countries. By providing income to local residents, ecotourists provide incentives to protect the resources they wish to view.

Turtle-based tourism activities have been introduced at a variety of nesting beaches around the world, often to serve different purposes (Figure 12.2). In the U.S., turtle walks are an educational tool designed to gain public support for protecting nesting beaches (Johnson et al., 1996). In Australia, ecotourism is promoted to provide an economic rationale for conserving the species (Wilson and Tisdell, 2001). In Tortuguero, Costa Rica, income earned by ecotourism can replace money earned formerly via a green turtle fishery (Jacobson and Robles, 1992; Peskin, 2002). At Playa Grande, Costa Rica, guided turtle walks generate income and awareness
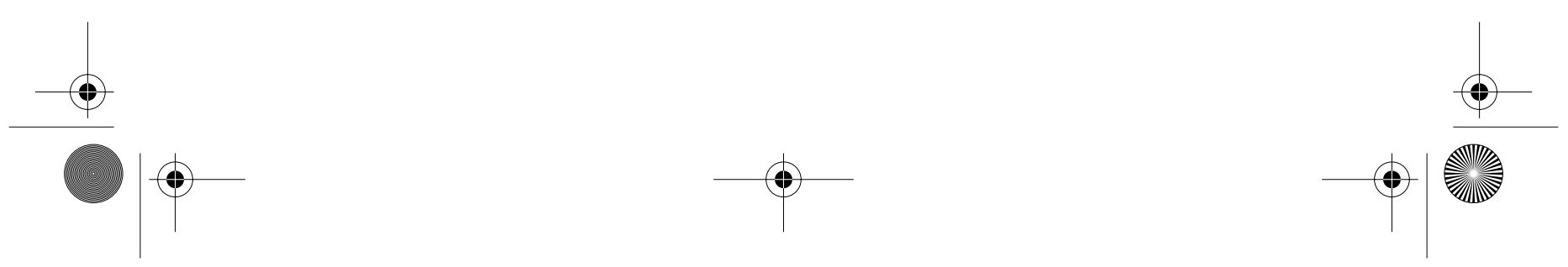


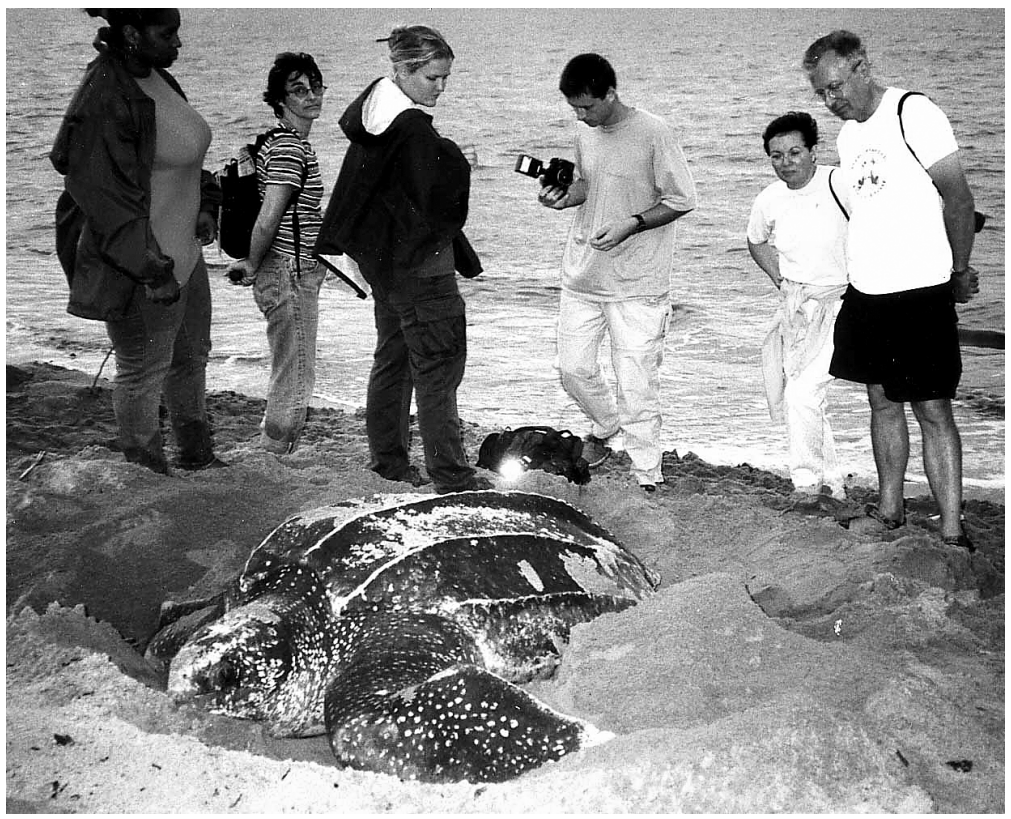

FIGURE 12.2 Viewing nesting leatherbacks in French Guiana, illustrating turtles as tourist activity. (From M. Godfrey and O. Drif. With permission.)

needed to justify maintaining a protected nesting beach in an area of dense tourism development (Campbell, in press a). Turtle-based activities, however, do not equate with true ecotourism. In the case of Playa Grande, for example, tourism development may be partly responsible for declining numbers of nesting leatherbacks. On the other hand, tourism at Tortuguero appears to be partially meeting the objectives of ecotourism (Campbell, in press a; Peskin, 2002).

Ecotourism in practice has often fallen short of its environmental, economic, and social objectives (Ross and Wall, 1999). Nevertheless, its perceived potential is high, and Godfrey and Drif (2001) suggest that "it is almost axiomatic to present the idea that developing ecotourism is a desirable goal" when undertaking sea turtle conservation projects. Enthusiasm for ecotourism is often linked to a lack of enthusiasm for consumptive turtle use (Campbell, 2000; Campbell, in press a). For the purposes of this chapter, it is not the actual success or failure of ecotourism ventures that is of interest, but the cultural context of and the values associated with turtlebased ecotourism ventures.

In any ecotourism scenario, turtles are valued in a variety of ways. In the example of Tortuguero, Costa Rica, there are several stakeholder groups interested in turtles. Tourists travel to Tortuguero to view turtles (Jacobson and Robles, 1992), guides leading turtle tours earn income (Peskin, 2002), scientists value the species conservation and the research opportunities afforded, and research assistants and participants working for the Caribbean Conservation Corporation (CCC) value their turtle experience for a variety of reasons (Smith, 2002). Prior to the establishment of Tortuguero National Park, turtles were a food, economic, and cultural resource for
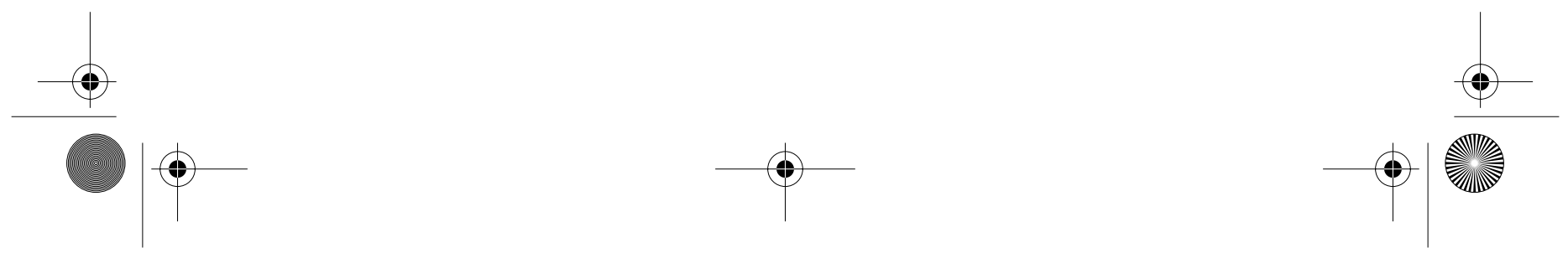
local people (Lefever, 1992). Although multiple values of turtles are coexisting in Tortuguero, some residents (primarily older, original inhabitants) would like to use limited numbers of turtles as a source of food (Peskin, 2002).

Turtles are also used to advertise or promote tourism destinations, as discussed in Section 12.2.3.4.

\subsubsection{Education}

Turtles are charismatic megafauna, and as such are a flagship species. Public education regarding sea turtle issues may have wider spillover effects, because successful conservation of sea turtle habitat, for example, has benefits for other less charismatic species. This argument has been made with TEDs; although they were designed specifically to release turtles from shrimp trawls, they also reduce general bycatch. Education is also an objective of turtle-based tourism or volunteer activities, both by the promoters and the participants. For example, in Tortuguero, Costa Rica, many individuals participating in the CCC's volunteer research programs are specifically motivated by the educational opportunity of working with turtles in the wild, and some are looking for materials they can use in their own teaching (Smith, 2002). Turtles are also kept in educational facilities; for example, Project TAMAR in Brazil keeps some turtles in various stages of captivity to serve as direct educational tools (Marcovaldi and Marcovaldi, 1999).

\subsubsection{Research}

Research with wildlife often involves the use of the species itself. Normally, and particularly in the case of endangered species, this use is nonconsumptive, i.e., the species is not permanently removed from a population, and research protocols are designed to minimize any long-term effects. Many of the contributors to this volume use turtles in their research, and have careers based on such work.

\subsubsection{Turtles as Symbols}

Although little research has been done in this field, it appears that, for many people, sea turtles are symbols of the marine environment, of environmentalism, and of the historic struggles between humans and nonhuman beings. Turtles are the subjects of material culture; songwriters, poets, painters, carvers, photographers, and sculptors use turtles as their subjects. The annual Symposium on Sea Turtle Biology and Conservation relies on attendees' willingness to purchase such material products at an auction as a means of fundraising.

Sea turtles appear on postage stamps (Figure 12.3). Stamps from 163 countries can be found at http://www.2xtreme.net/nlinsley/)

In this role, marine turtles are a symbol of national identity and environmental consciousness. Sea turtles are also used as marketing tools, and lend enviro-credibility to products (e.g., www.greenturtle.com). Some research has been done on the use of sea turtles to promote tourism (Cosijn, 1995; Schofield et al., 2001). Although critical of using sea turtles to market mass tourism, the studies have focused on the correctness of information provided in tourist brochures. Cosijn (1995) sees this use 
of turtles as a tool to "seduce people into buying their travel product." The attractiveness of turtles is speculated on, rather than studied, but the researchers and the tour companies recognize the symbolic role of sea turtles in the imaginations of potential tourists.

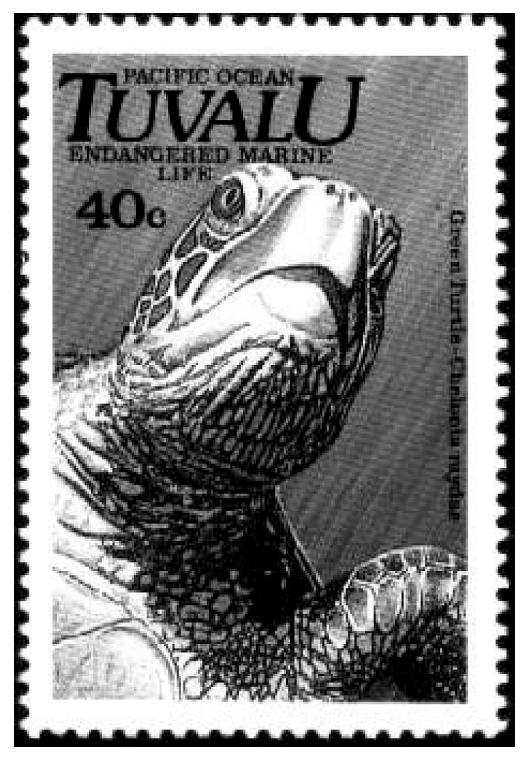

FIGURE 12.3 Tuvala postage stamp, illustrating turtles as a national symbol.

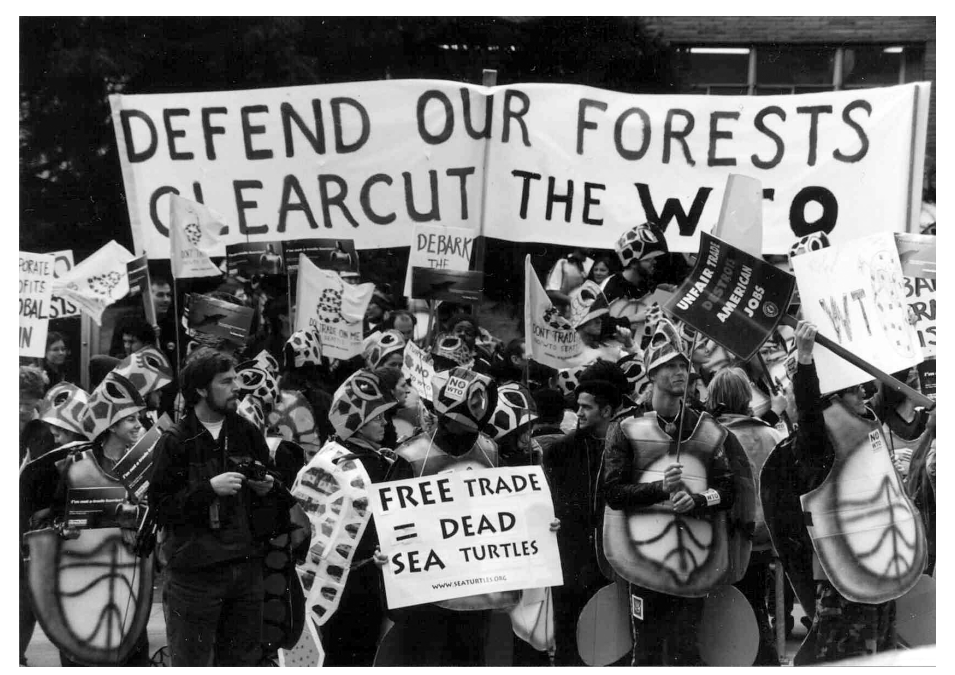

FIGURE 12.4 Protesters at the WTO meetings in Seattle: turtles as a symbol of the anitglobalization movement. 
In 1999, sea turtles were a focal point of protests at WTO meetings in Seattle, WA. A subgroup of protestors who focused on the issue of TED use in shrimp trawls costumed themselves as sea turtles, and their images were picked up by the media (Figure 12.4).The turtle protestors became a symbol of an antiglobalization movement in general, one that can be considered a form of counterculture, challenging the promotion of global free trade and associated global values (Yuen et al., 2001). (Whether the original protestors identify themselves with the wider movement and all its values is unknown). In Seattle and at other related protests, the clash of values was paramount and encompassed nothing less than the very structure of economic, political, and social life.

\subsection{CULTURE AND CONSERVATION: CULTURES OF CONSERVATION}

Section 12.2 illustrates some of the uses of sea turtles (consumptive and nonconsumptive) and the ways that culture mediates such use. As discussed in Section 12.1.3, where the cultural context of the National Park model was described, cultures also influence conservation. The conservation concepts of sustainable use and CBC, their application to sea turtles, how they reflect the interaction of culture and conservation, and how they fit into cultures of conservation, are examined below.

\subsubsection{Sustainable UsE}

\subsubsection{Concept}

According to the IUCN, sustainable use is central to contemporary conservation (Section 12.1.3). Sustainable use is generally defined as the managed use of resources in a way and at a rate that does not compromise their long-term existence. Use can be either consumptive or nonconsumptive, providing subsistence or commercial benefits (Freese, 1998). Sustainable use is often an objective of management rather than a certainty, because of the difficulties in determining definitively the outcomes of use schemes, and because of the reality that sustainable use programs are often implemented as alternatives to uncontrolled exploitation.

Sustainable use is based on the argument that wildlife and biodiversity must be valued by those expected to conserve it, and that value is often derived through use: "if wildlife has no value, then wildlife and its habitat will be destroyed to make way for other land uses" (Robinson and Redford, 1991). In the case of impoverished rural peoples, the most compelling value is assumed to be economic and, although this reduction of local values for wildlife to economic ones is oversimplified, it reflects the pervasiveness and reality of the market economy.

Sustainable use is the subject of much debate. The number of successful cases of sustainable use, and particularly of commercial, consumptive use, of wildlife is low (Freese, 1998). Difficulties are related to biological sustainability (e.g., the inability of resources to sustain even low levels of use, or predicting correctly the response of a population to use), and long-lived animals with slow reproductive rates and low levels of density dependence pose particular challenges for use regimes 
(Robinson, 1993; Musick, 1999). Other difficulties relate to socioeconomic sustainability (e.g., establishing incentives that encourage long-rather than short-term views to use). Even when managed use schemes are believed to be biologically sound and return economic benefits to local people, they may fail to gain support for conservation if control over resources is not devolved to local users. This lack of support can translate into illegal use of managed resources and undermine overall sustainability. CBC, which in part arose in response to issues of control, is discussed in Section 12.3.2.

\subsubsection{Sustainable Use and Sea Turtle Conservation}

Sustainable use projects that involve consumptive use of sea turtles for conservation purposes are few. One example is egg collection at Ostional, Costa Rica (Campbell, 1998; Cornelius et al., 1991). Similar, but less documented collections take place in Panama (Evans and Vargas, 1998) and Nicaragua (Ruiz, 1994). These collections are based on arribada nesting by olive ridleys, i.e., mass nesting that destroys many eggs, and the Ostional project is the only olive ridley collection where commercial sale of eggs is legal. In Suriname, leatherback and green turtle eggs that would otherwise be inundated and/or washed by an eroding shoreline are collected by both communities and the government agency responsible for National Parks. Collected eggs are sold, and generate public support for conservation as well as income for conservation activities (Mohadin, 2000).

In other places, use of turtles or eggs is allowed, but at such low levels that biological sustainability is not a prime concern. These are instances of what might be termed minimal compensatory use. For example, a small harvest of leatherback eggs by the community at Gandoca was allowed in the Gandoca and Manzanillo Wildlife Refuge, Costa Rica, until the late 1990s. Such compensatory use programs seek to ensure community support for broader conservation goals:

Information collected from Gandoca residents shows that community support for the project will increase, and poaching by locals will be reduced if local residents are permitted to consume moderate numbers of eggs in a controlled manner. In many cases it appears that what matters is not so much whether a given family obtains eggs as that they do not feel prohibited from doing so.

ANAI, 1995

This type of compensatory collection has also been seen with some adult fishing operations. Examples from Tortuguero National Park and Limon, Costa Rica, have been discussed (Section 12.2.1.1). Similarly, in 1980 in one region of Mexico, the government switched from a closed turtle fishing season to a quota system that allowed 250 male green turtles to be used by a local cooperative. This had the impact of changing the attitudes of coop members, who stopped illegal use and began to accept the turtle recovery program (Clifton et al., 1995).

Sustainable use is controversial in sea turtle conservation. The Marine Turtle Specialist Group (MTSG) of the IUCN has promoted a no-use stance for most of its history (Campbell, in press b). For example, the 1979 World Conference on Sea Turtle Conservation cited "the use of sea turtles as food by people who live where 
sea turtles are found" and "differing attitudes toward conservation in different countries" as factors contributing to sea turtle decline (Bjorndal, 1981). The 1979 meeting did make a concession to use, when it was "a traditional way of obtaining food practiced by aboriginal people who are not yet part of a cash economy or technological society" (Bjorndal, 1981). As the discussion of key terms in Section 12.1.4 suggests, limiting use of marine turtles along these lines, where culture and economy are static, is problematic. Nevertheless, many marine turtle experts support such limits on use (Campbell, 2000).

These 1979 sentiments reflect the dominant culture of conservation of the time, one that relied on a traditional approach via the National Park model. (A later manual on conservation techniques recommends that poachers be kept away from nesting beaches by patrolling "with assistance from military organizations, conservation officials and interested amateurs" [Pritchard, 1983].) Early proponents of local use existed within the MTSG, however, and Hughes (1979) argued that marine turtles are "extremely resilient" to exploitation: "Where total protection is feasible, let us have it; where not, let us not close the door to survival by ignoring a valid conservation technique - utilization." Similarly, Mrosovsky (1979), Reichart (1982), and Bustard (1980) made the argument for use where socioeconomic, political, and cultural conditions warranted it.

These early views in support of consumptive use of marine turtles reflect contemporary discussions of sustainable use. Over time, the MTSG's position on sustainable use has shifted slightly. For example, the 1995 Global Strategy for the Conservation of Marine Turtles (the Strategy [MTSG, 1995]) recognizes that turtles play a role in the cultural and social lives of coastal people and are an important source of protein. However, it stops short of accepting sustainable use:

Too frequently... wide use by a growing human population, coupled with the migratory nature and slow rates of natural increase of these animals, has resulted in most utilization being non-sustainable....Although this Strategy recognizes that utilization of marine turtles occurs in many areas and does not oppose all use, it does not support non-sustainable use.

MTSG, 1995

To date, there are no accepted guidelines for marine turtle use, although there was an opportunity for the MTSG to provide egg collecting guidelines in a recently published techniques manual (Eckert et al., 1999), as suggested in the Strategy (MTSG, 1995).

Campbell (in press b; 2000) examined attitudes of sea turtle conservation experts toward sustainable use. Although experts agree that biological characteristics of marine turtles constrain the extent to which sea turtles can be used with certainty, their views on how to proceed from this starting point differ. It is on moving from this point that the cultures of conservation become most evident. Although almost all experts believe their views on sustainable use are informed by science, other values clearly play a role. For example, views on local rights to use resources and on local socioeconomic and cultural need impact on expert positions on use (Campbell, 2000). Very few experts recognize their own emotional response to sea turtles; they see their views as informed by science and value free, whereas they characterize the views of others, particularly 
those who disagree with them, as value laden (Campbell, in press b). Finally, the way that experts address issues of scientific uncertainty influences their views on use (Campbell, in press b). Science as a foundation of Western culture in general, and its influence on conservation policy specifically, are themselves subjects of study (Leach and Mearns, 1996; Nader, 1996; Pepper, 1984).

\subsubsection{CBC}

\subsubsection{Concept}

Like sustainable use, CBC assumes that support of local people is critical to conservation success. The terms differ in their foci; although sustainable use focuses on the use of the species itself, $\mathrm{CBC}$ is concerned with the local economic, social, and cultural context in which conservation takes place, and with the role of communities in conservation projects (regardless of whether they have a use component). There is no one definition of $\mathrm{CBC}$, but it is commonly seen as having two objectives: to enhance conservation and to provide social and economic gains for local people. Ownership of conservation activities is a critical concern in CBC, and Little (1994) suggests that CBC implies "at least some of the following: local-level, voluntary, people-centered, participatory, decentralized, village based management." Nevertheless, there is a wide spectrum of views on $\mathrm{CBC}$, and the mix of components and prioritization of objectives vary according to the definer.

Like sustainable use, $\mathrm{CBC}$ has experienced mixed success in practice. Some of the major obstacles are, first, that CBC implementers fail to operationalize community participation in project identification, design, and management. Participation is instead seen as a means to get people to support predetermined conservation programs (Hackel, 1999; Songorwa, 1999). Second, CBC projects have been undertaken without an adequate understanding of the local social, economic, and cultural context and by environmental nongovernmental organizations (NGOs) with limited experience in community development (Wells and Brandon, 1993). Third, CBC has not learned from the related field of participatory development, where organizations primarily interested in human development have struggled to implement successful participation (Little, 1994). Community itself is emerging as a problematic term and communities are too often assumed to be homogeneous (Section 12.1.4). Although conservation can function in heterogeneous communities, understanding community structure is necessary to determine appropriate and realistic incentives for conservation (Campbell, 1998).

\subsubsection{CBC and Sea Turtle Conservation}

There are several accounts of community participation in sea turtle conservation, including stories of former poachers turned conservationists, of fishermen collecting data for conservation projects, and of communities participating in educational programs (e.g., Schulz, 1975; Nichols et al., 2000; Lima, 2001). The extent to which such projects are community based is unknown, because research on the extent of community support for conservation is lacking, and descriptions of success are often provided by conservation organizations themselves. Becuase "the goal of true $\mathrm{CBC}$ 
facilitators is to work themselves out of a job" (Frazier, 1999), the ultimate test of CBC's success is whether conservation efforts continue in the absence of conservation organizations - a test most organizations are unlikely to face. Four projects that show indications of being community based or are often cited as being community based are described briefly below.

\subsection{Costa Rica}

In the egg collection project at Ostional, Costa Rica, a community development association is responsible for almost all aspects of the conservation program. Community management is mandated by law, and although the University of Costa Rica and various government agencies are involved in the project, none is permanently present in the village. Campbell (1998) describes project regulation, economic value, and dependence on the project; use of profits in support of conservation and development projects; and willingness of community members to undertake additional sea turtle conservation efforts. An important conclusion from Campbell's (1998) work is that $\mathrm{CBC}$ should not be romanticized. In the Ostional case, high levels of intracommunity conflict detract only marginally from achievement of overall objectives.

\subsection{Mexico}

Community-based research and conservation have been promoted in Baja, California. Nichols et al. (2000) describe the need for a community approach in an isolated region with limited enforcement. They point out that researchers often focus on the ways local people detract from conservation, and that local values are oversimplified by outsiders: "local fishers have demonstrated an interest in conservation for ecological and aesthetic reasons, as well as to preserve a source of their traditional livelihood and an occasional source of food" (Nichols et al., 2000). In-water work at Bahía Magdalena by Nichols et al., for example, has relied on cooperation of local fishermen to show where turtles are regularly found and captured. Cultural motivations for exploitation are also recognized as critical to devising conservation schemes in the region. For example, because most turtles are eaten for special occasions and ceremonial feasts, attempts at substitutionmay be limited (Bird, in press). Although research and conservation efforts were initiated by outsiders in Bahía Magdalena, a grass roots organization has since formed to promote sea turtle recovery in the region. A recent decision by fishermen to exclude those who hunt turtles from participating in research activities reflects the extent to which conservation ideas are becoming community based (Nichols, personal communication, 2002).

\subsection{Australia}

In northern Australia, a collaboration between an indigenous community (the Yolngu of northeast Arnhem Land of the Northern Territory, represented by the Dhimurru Land Management Aboriginal Corporation), and university and government researchers has been undertaken to develop a strategy for sustainable subsistence use of turtles. The project is based on a recognition of both the rights and responsibilities of Australian aboriginals in managing the sea turtle resource, and that their involvement in research and management activities will be critical to the survival of sea turtles in the region. The project combines traditional knowledge and law with contemporary scientific methods (Kennett et al., 1997). Activities have included
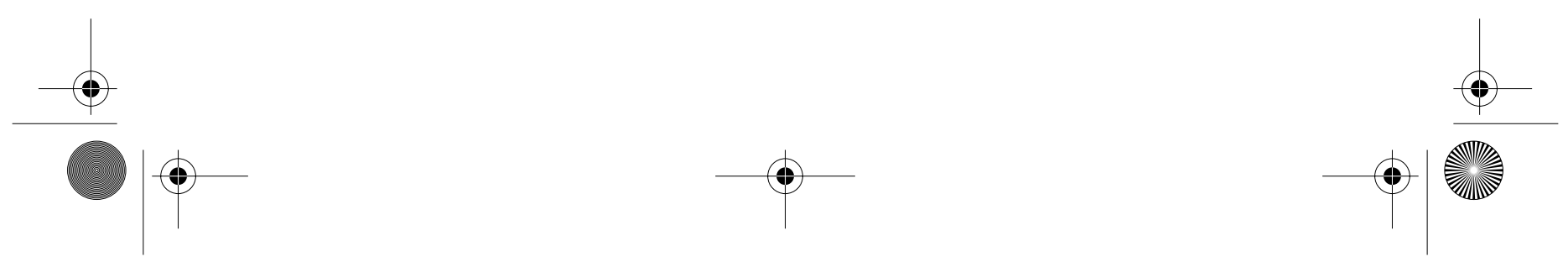
recording traditional knowledge, a turtle stranding and rescue program, heavy metal analysis, habitat mapping, tagging and nesting studies, satellite tracking, genetic sampling, studies of temperature and sex determination, and quantifying indigenous harvests (R. Kennett, personal communication, 2002).

\subsection{Brazil}

Project TAMAR covers a large portion of the Brazilian coast and has been described in detail by Marcovaldi and Marcovaldi (1999). The geographic spread of the project means that many communities are impacted, and their experiences undoubtedly differ. Nevertheless, TAMAR's approach to CBC has generally been two-pronged: environmental education and provision of alternative economic activities. In one example, TAMAR set up a field station in the indigenous settlement of Almofala, where incidental catch of marine turtles in fishing operations was a concern. In addition to extensive environmental education activities, TAMAR assisted the local community to develop alternative economic activities, including artificial reefs for fishing, a community vegetable garden, and embroidery and lace making, as identified at a meeting between TAMAR and a community association (Lima, 2001).

Communities and their importance to conservation undertakings are increasingly included in the dominant culture of sea turtle conservation. The annual Symposium on Sea Turtle Biology and Conservation has expanded in scope over the last 8 years and now includes several sessions devoted to the interaction of conservation and communities. Nevertheless, messages about community involvement remain mixed in official policy. Although the MTSG's 1995 Strategy (1995) calls for local participation because local people are "a strong force in the depletion of marine turtle populations and the destruction of their habitats," the 1999 Techniques Manual includes a chapter on CBC that depicts local people as potential partners with vested interests in the continued existence of resources (Frazier, 1999). The recently negotiated Inter-American Convention for the Protection and Conservation of Sea Turtles has been criticized for its "top-down" approach and its failure to incorporate CBC (Campbell et al., in press). In contrast, the Santo Domingo Declaration resulting from the regional meeting, Marine Turtle Conservation in the Wider Caribbean Region - A Dialogue for Effective Regional Management, calls for "greater community participation in the identification of management priorities and actions, as well as in the development, implementation and evaluation of activities directed at the conservation of sea turtles and their habitats" (Eckert and Abreu, 2001). It recognizes that "sea turtles comprise a unique part of the biological diversity of the region and an integral part of the cultural, economic, and social aspects of the societies found therein" (Eckert and Abreu, 2001). In a study of marine turtle experts and their views on conservation, Campbell (2000) found that although experts were highly supportive of local participation, their definitions of participation were often limited to being employed by a conservation program, educated, and listened to. In such cases, objectives of conservation programs were assumed, and experts were generally opposed to relinquishing control over conservation programs to local people. Given the mixed treatment of community in the dominant culture of conservation, claims of projects being community based need to be carefully considered, and research on the extent of support for conservation among communities is needed.
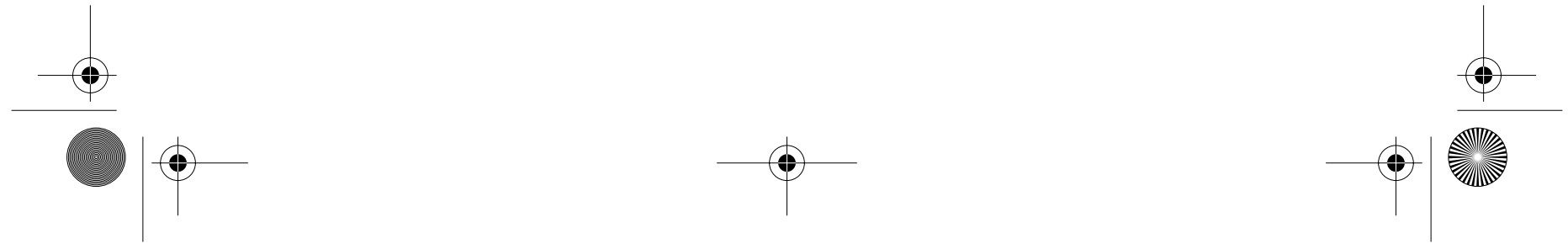


\subsection{CONCLUSIONS}

On the basis of this review, three conclusions are highlighted:

1. The ways that culture influences the use and conservation of sea turtles are varied and, beyond the generalization that culture needs attention, there are currently few rules to share across regions and peoples. For example, the common observation that market infiltration undermines culture and makes use unsustainable is not true in all cases. Further sitespecific research is needed, because the number of research-based assessments of the culture-conservation link are few; many of the authors cited in this chapter reflect on cultural issues rather than study them. Such research will serve to improve conservation in specific contexts, and accumulation of research might yield more generalizable results.

2. The notion that only certain kinds of cultures (indigenous, traditional, or subsistence) are relevant for sea turtle use is misleading. The importance of these issues in influencing use, and their relevance in a global economy, are not entirely clear. For example, insistence that, if local people are in the market they lose any claims to tradition or culture, regardless of how marginalized they are within a global economic system, is an inaccurate characterization of culture as static, and may only serve to further impoverish rural peoples in developing countries. Instances of use need to be assessed on their cultural, social, economic, and environmental impacts, rather than on the extent to which they fulfill Western notions of what is traditional.

3. Culture is not only something that influences use and conservation of marine turtles in some other, more exotic, locale. Cultural values are evident in all uses of marine turtles, and conservation, although often depicted as value free, is itself a product of culture. Even the importance placed on science in conservation policy is a reflection of Western culture (Pepper, 1984). Recognizing the diversity of cultural relations with sea turtles and the cultural context of conservation policy may make such policy more flexible and dynamic, and more acceptable to and appropriate for the diversity of people living with sea turtles.

\section{ACKNOWLEDGMENTS}

The author's research is supported by the Canadian Social Sciences and Humanities Research Council. Jack Frazier contributed to the intellectual foundations of this paper and provided detailed comments on various drafts. Matthew Godfrey commented on two drafts, and tracked down and shared needed references. Thanks to the editors for providing the opportunity for this contribution and for their patience with its production. 


\section{REFERENCES}

Addison, D.S. 1995. Poaching in Everglades City, Florida, trivialized by sentences. Mar. Turtle Newsl. 69: 16.

ANAI. 1995. Conservation of the Leatherback Turtle in Gandoca/Manzanillo National Wildlife Refuge: Volunteers Manual. ANAI. San Jose, Costa Rica.

Anonymous. 1977. Indian Ocean tourists wiping out sea turtles. Mar. Turtle Newsl. 7: 4.

Anonymous. 1995. Guest editorial: endangered species vs. property rights. Mar. Turtle Newsl. 70: 15 .

Anonymous. 2001. Fur's dirty dozen. Anim. Agenda. 21: 10.

Aureggi, M., G. Gerosa, and S. Chantrapornsyl. 1999. Marine turtle survey at Phra Thong Island, South Thailand. Mar. Turtle Newsl. 85: 4.

Avis, W.S., ed. 1980. Funk \& Wagnalls Standard College Dictionary. Fitzhenry \& Whiteside Limited, Toronto. 1590 pp.

Balazs, G.H. 1977. Sale of turtle products promoted in Hawaii. Mar. Turtle Newsl. 4: 4.

Balazs, G.H. 1995. Hawaiian Islands: promoting sea turtle watching in coastal waters of the Hawaiian Islands to enhance conservation and ecotourism. National Marine Fisheries Service, Honolulu, HA.

Berkes, F., J. Colding, and C. Folke. 2000. Rediscovery of traditional ecological knowledge as adaptive management. Ecol. Appl. 10: 1251.

Bird, K. In press. Integrating local knowledge and outside knowledge in sea turtle conservation: a case from Baja California, Mexico. In Proceedings of the 22nd Annual Symposium on Sea Turtle Biology and Conservation.

Bjordnal, K.A. 1981. Biology and Conservation of Sea Turtles. Smithsonian Institution Press, Washington, DC.

Braun, B. and N. Castree. 1998. Remaking Reality. Routledge, London. 312 pp.

Brosius, J.P., A. Lowenhaupt Tsing, and C. Zerner. 1998. Representing communities: histories and politics of community-based natural resource management. Soc. Nat. Resour. 11: 157.

Bustard, H.R. 1980. Should sea turtles be exploited? Mar. Turtle Newsl. 15: 5.

Campbell, L.M. 1997. International conservation and local development: the sustainable use of marine turtles in Costa Rica. Ph.D. thesis, University of Cambridge, Cambridge. xiii +347 pp.

Campbell, L.M. 1998. Use them or lose them? The consumptive use of marine turtle eggs at Ostional, Costa Rica. Environ. Conserv. 24: 305.

Campbell, L.M. 1999. Ecotourism in rural developing communities. Ann. Tourism Res. 26: 534.

Campbell, L.M. 2000. Human need in rural developing areas: perceptions of wildlife conservation experts. Can. Geogr. 44: 167.

Campbell, L.M. In press, a. Conservation narratives and the 'received wisdom' of ecotourism: case studies from Costa Rica. Intl. J. Sustainable Dev.

Campbell, L.M. In press, b. Sustainable use of marine turtles: views of conservation experts. Ecol. Appl.

Campbell, L.M., M.H. Godfrey, and O. Drif. In press. Community based conservation via global legislation? Limitations of the Inter-American Convention for Protection and Conservation of Sea Turtles. J. Int. Wildl. Law Policy.

Carr, A. 1967. The Windward Road: Adventures of a Naturalist on Remote Caribbean Shores. Alfred A. Knopf, New York.

Carr, A. 1977. Crisis for the Atlantic ridley. Mar. Turtle Newsl. 4: 2. 
Carrillo, C.E., G.J. Webb, and S.C Manolis. 1999. Hawksbill turtles (Eretmochelys imbricata) in Cuba: an assessment of the historical harvest and its impacts. Chelonian Conserv. Biol. 3: 264.

Cheng, I.-J. 1995. Tourism and the green turtle in conflict on Wan-An Island, Taiwan. Mar. Turtle Newsl. 68: 4.

Cornelius, S.E. et al. 1991. Management of olive ridley sea turtles (Lepidochelys olivacea) nesting at playas Nancite and Ostional, Costa Rica. In Neotropical Wildlife Use and Conservation. Robinson, J.G., and K.H. Redford, eds. University of Chicago Press, Chicago. $111 \mathrm{pp}$.

Cosijn, J. 1995. Using sea turtles for tourism marketing. Mar. Turtle Newsl. 71: 12.

Crouse, D. 1999. Guest editorial: the WTO shrimp/turtle case. Mar. Turtle Newsl. 83:1.

Dempsey, M. 1996. Turtles and tourists get special attention. In Profiles: the Magazine of Continental Airlines (April 17).

Dimopoulos, D. 2001. The National Marine Park of Zakynthos: a refuge for the loggerhead turtle in the Mediterranean. Mar. Turtle Newsl. 93: 5.

Donnelly, M. 1994. Sea Turtle Mariculture: A Review of Relevant Information for Conservation and Commerce. Center for Marine Conservation, Washington, DC.

Eckert, K.L. et al, eds. 1999. Research and Management Techniques for the Conservation of Sea Turtles. Publication No. 4, IUCN/SSC Marine Turtle Specialist Group. 235 pp.

Eckert, K.L. and F.A. Abreu. 2001. Marine turtle conservation in the wider Caribbean region: a dialogue for effective regional management. Mar. Turtle Newsl. 94: 12.

Ecotourism Society. Frequently asked questions; available online at http://www.ecotourism.org/tiessvsfr.html.

Ellen, R. and K. Fukui. 1996. Redefining Nature: Ecology, Culture and Domestication. Berg, Oxford. 664 pp.

Escobar, A. 1992. Planning. In The Development Dictionary: A Guide to Knowledge as Power. Sachs, W., ed. Zed Books, London. 132 pp.

Escobar, A. 1999. After nature. Curr. Anthropol. 41: 1.

Evans, K.E. and A.R. Vargas. 1998. Sea turtle egg commercialization in Isla de Canas, Panama. In Proceedings of the 16th Annual Symposium on Sea Turtle Biology and Conservation. Byles, R. and Y. Fernandez, eds. 45 pp.

Fletemeyer, J. R. 1996. Guest editorial: the shot heard around the world - Volusia sea turtle suit. Mar. Turtle Newsl. 72: 16.

Fortes, O., A.J. Pires, and C. Bellini. 1998. Green turtle, Chelonia mydas, in the Island of Poilão, Bolama-Bijagós Archipelago, Guinea-Bissau, West Africa. Mar. Turtle Newsl. 84: 4.

Fournillier, K. 1994. Integrating endangered species conservation and ecotourism: marine turtle management in North-East Trindad. In Tourism and Marine Turtles: Can We Live Together? IUCN-MTSG Committee on the Impact of Tourism on Marine Turtles.

Frazier, J. In press. Science, conservation and sea turtles: what's the connection? In Proceedings of the 21 st Annual Symposium on Sea Turtle Biology and Conservation. Philadelphia.

Frazier, J. 1999. Community-based conservation. In Research and Management Techniques for the Conservation of Sea Turtles. Publication No. 4. Eckert, K.L. et al., eds. IUCN/SSC Marine Turtle Specialist Group. 15 pp.

Freese, C.H. 1998. Wild Species as Commodities: Managing Markets and Ecosystems for Sustainability. Island Press, Washington, DC. 319 pp.

Ghimire, K.B. and M.P. Pimbert. 1997. Social Change and Conservation. Earthscan, London. $342 \mathrm{pp}$.

Godfrey, M.H. and O.D. Drif. 2001. Guest editorial: developing sea turtle ecotourism in French Guiana: perils and practicalities. Mar. Turtle Newsl. 91: 1. 
Gutic, J. 1994. Sea turtle eco-tourism brings economic benefit to community. Mar. Turtle Newsl. 64: 10.

Hackel, J.D. 1999. Community conservation and the future of Africa's wildlife. Conserv. Biol. 13: 726

Hoinsoude, G.S. et al. In press. Plan for sea turtle conservation in Togo. In Proceedings of the 22nd Annual Symposium on Marine Turtle Biology and Conservation.

Hughes, G.R. 1979. Conservation, utilization, antelopes and turtles. Mar. Turtle Newsl. 13: 13. Islam, M.Z. 2001. Notes on the trade in marine turtle products in Bangladesh. Mar. Turtle Newsl. 94: 10.

IUCN. 1980. The World Conservation Strategy. World Conservation Union (IUCN), Gland, Switzerland.

Jacobson, S.K. and R. Robles. 1992. Ecotourism, sustainable development, and conservation education: development of a tour guide training program in Tortuguero, Costa Rica. Environ. Manage. 16: 701.

Johnson, S.A., K.A. Bjorndal, and A. Bolten. 1996. A survey of organized turtle watch participants on sea turtle nesting beaches in Florida. Chelonian Conserv. Biol. 2: 60.

Juarez, R. and C. Muccio. 1997. Sea turtle conservation in Guatemala. Mar. Turtle Newsl. 77: 15 .

Kaneko, Y. and H. Yamaoka. 1999. Traditional use and conservation of hawksbill turtles: from a Japanese industry's perspective; available online at http://www.iwmc.org/sustain/2ndsymposium/aquatic/aquatic-22-1/htm.

Kar, C.S. and S. Bhaskar. 1982. Status of sea turtles in the eastern Indian Ocean. In Biology and Conservation of Sea Turtles. Bjorndal, K.A., ed. Smithsonian Institution Press, Washington, DC. 365 pp.

Kempton, W., J.S. Boster, and J.A. Hartley. 1995. Environmental Values in American Culture. MIT Press, Cambridge, MA. 320 pp.

Kennett, R.M. et al. 1997. Nhaltjan Nguli Miwatj Yolngu Djaka Miyapunuwu: Sea turtle conservation and the Yolngu people of north east Arnhem Land, Australia. In Principles of Conservation Biology. Meffe, G., ed. Sinauer Associates, Sunderland, MA. $426 \mathrm{pp}$.

Kostyack, J. 1999. FL Turtle lawsuit; available online at www.lists.ufl.edu/cgi-bin/wa?A2 = ind $9904 \& \mathrm{~L}=$ cturtle $\& \mathrm{D}=0 \& \mathrm{P}=11746$, CTURTLE archives.

Kowarsky, J. 1995. Subsistence hunting of sea turtles in Australia. In Biology and Conservation of Sea Turtles, revised edition. Bjorndal, K., ed. Smithsonian Institution Press, Washington, DC. 305 pp.

Lagueux, C. 1991. Economic analysis of sea turtle eggs in a coastal community on the Pacific coast of Honduras. In Neotropical Wildlife Use and Conservation. Robinson, J.G. and K.H. Redford, eds. University of Chicago Press, Chicago.

Lagueux, C. 1998. Marine turtle fishery of Caribbean Nicaragua: human use patterns and harvest trends. Ph.D. thesis, University of Florida, Gainesville, FL. 215 pp.

Leach, M. and R. Mearns. 1996. Introduction. In The Lie of the Land: Challenging Received Wisdom on the African Environment. Leach, M. and R. Mearns, eds. The International African Institute, Oxford, U.K.

Leach, M., R. Mearns, and I. Scoones. 1997. Editorial: community-based sustainable development: consensus or conflict? IDS Bull. 4: 1.

Lefever, H.G. 1992. Turtle Bogue: Afro-Caribbean Life and Culture in a Costa Rican Village. Associated University Press, Cranbury. 249 pp.

Lima, E.H., 2001. Helping the people help the turtles: the work of projecto TAMAR-IBAMA in Almofala, Brazil. Mar. Turtle Newsl. 91: 7. 
Little, P. 1994. The link between local participation and improved conservation: a review of issues and experiences. In Natural Connections: Perspectives in Community-Based Conservation. Western, D. and M.A. Wright, eds. Island Press, Washington, DC. 347 pp.

Lopez, M. and A. Fallabrino. 2001. New kind of illegal trade of marine turtles in Uruguay. Mar. Turtle Newsl. 91: 10.

Lyver, P.O. and H. Moller. 1999. Modern technology and customary use of wildlife: the harvest of sooty shearwaters by Rakiura Maori as a case study. Environ. Conserv. 26: 288.

March, E. 1992. Diagnostico sobre situacion social de la poblacion de Ostional, Provincia de Guanacaste, Asociación de Desarollo Integral de Ostional, Ostional, Costa Rica.

Marcovaldi, M.A. and G. Marcovaldi. 1999. Marine turtles of Brazil: the history and structure of Projeto TAMAR-IBAMA. Biol. Conserv. 91: 35.

Margavio, A. and C. Forsyth. 1996. Caught in the Net: The Conflict Between Shrimpers and Conservationists. Texas A\&M University Press, College Station, TX.

Marks, S. 1984. The Imperial Lion: Human Dimensions of Wildlife Management in Central Africa. Bowker, Epping, U.K.

McCormick, J. 1989. The Global Environmental Movement: Reclaiming Paradise. Belhaven, London.

McCoy, M. 1995. Subsistence hunting of turtles in the Western Pacific: the Caroline Islands. In Biology and Conservation of Sea Turtles, revised edition. Bjorndal, K., ed. Smithsonian Institution Press, Washington, DC. 275 pp.

Miller, J.D. 1989. Marine Turtles. Vol. 1, An Assessment of the Conservation Status of Marine Turtles in the Kingdom of Saudi Arabia. Meteorology and Environmental Protection Administration. Coastal and Marine Management Series.

Miller, J. 2000. Editorial: listening to the elders. Mar. Turtle Newsl. 88: 1.

Mohadin, K. 2000. Sea turtle research and conservation in Suriname: history, constraints and achievements. In Proceedings of the 3rd Meeting on the Sea Turtles of the Guianas. Kelle, L. et al., eds.

Mortimer, J. 1977. Final approach to Bali airport. Mar. Turtle Newsl. 5.

Mortimer, J.A. and J. Collie. 1998. Status and conservation of sea turtles in the Republic of Seychelles. In Proceedings of the 17th Annual Sea Turtle Symposium. Epperly, S.P. and J. Braun, eds. Orlando, FL. 70 pp.

Mrosovsky, N. 1979. Editorial. Mar. Turtle Newsl. 13: 1.

Mrosovsky, N. 2000. Sustainable Use of Hawksbill Turtles: Contemporary Issues in Conservation. Key Centre for Tropical Wildlife Management, Darwin. 107 pp.

MTSG. 1995. A Global Strategy for the Conservation of Marine Turtles. World Conservation Union (IUCN), Gland, Switzerland.

Musick, J. A. 1999. Life in the Slow Lane; Ecology and Conservation of Long-Lived Marine Animals. American Fisheries Society Symposium 23. Bethesda, MD.

Nabhan, G. et al. 1999. Sea turtle workshop for indigenous Seri tribe. Mar. Turtle Newsl. 86: 14.

Nader, L. 1996. Naked Science: Anthropological Inquiry into Boundaries, Power, and Knowledge. Routledge, New York.

Nichols, W.J., K.E. Bird, and S. Garcia. 2000. Community-based research and its application to sea turtle conservation in Bahía Magdalena, BCS, Mexico. Mar. Turtle Newsl. 89: 4.

Nietschmann, B. 1973. Between Land and Water: The Subsistence Ecology of the Miskito Indians, Eastern Nicaragua. Seminar Press, New York. 279 pp.

Nietschmann, B. 1979. Caribbean Edge: The Coming of Modern Times to Isolated People and Wildlife. Bobs-Merrill, Indianapolis, IN. 280 pp. 
Opay, P. 1998. Legal action taken to stop the hunting of green turtles in Costa Rica. Mar. Turtle Newsl. 79: 12.

Parra, L. et al. 2000. The sea turtle and its social representation in the Wayuu indigenous culture, Zulia State, Venezuela. In Proceedings of the 19th Annual Symposium on Sea Turtle Biology and Conservation. Kalb, H.J. and T. Wibbels, eds. 207 pp.

Parsons, J. 1962. The Green Turtle and Man. University of Florida Press, Gainesville, FL. $126 \mathrm{pp}$.

Pepper, D. 1984. The Roots of Modern Environmentalism. Croom Helm, London.

Peskin, J. D. 2002. Local guides' attitudes toward ecotourism, sea turtle conservation, and guiding in Tortuguero, Costa Rica. M.S. thesis, University of Florida, Gainesville, FL. 86 pp.

Place, S.E. 1991. Nature tourism and rural development in Tortuguero. Ann. Tourism Res. 18: 186.

Plotkin, P. 1999. Resolutions of the participants at the 19th Annual Symposium on Sea Turtle Biology and Conservation. Mar. Turtle Newsl. 85: 20.

Pritchard, P. et al. 1983. Protecting nesting beaches. In Manual of Sea Turtle Research and Conservation Techniques, 2nd edition. Bjorndal, K and G.H. Balazs, eds. Center for Environmental Education, Washington, DC.

Reichart, H.A. 1982. Farming and ranching as a strategy for sea turtle conservation. In Biology and Conservation of Sea Turtles. Bjorndal, K.A., ed. Smithsonian Institute, Washington, DC. 465 pp.

Richardson, P. 2000. Guest editorial: obstacles to objectivity: first impressions of a CITES CoP. Mar. Turtle Newsl. 89: 1.

Robert, _. 1992. Production. In The Development Dictionary: A Guide to Knowledge as Power. Sachs, W., ed. Zed Books, London. 177 pp.

Roberts, A.M., G. Gabriel, and J. Robinson. 1999. Dying to heal: The use of animals in traditional medicine. Anim. Agenda 19: 30.

Robinson, J.G. 1993. The limits to caring: sustainable living and the loss of biodiversity. Conserv. Biol. 7: 20.

Robinson, J.G. and K.H. Redford. 1991. The use and conservation of wildlife. In Neotropical Wildlife Use and Conservation. Robinson, J.G. and K.H. Redford, eds. University of Chicago Press, Chicago. p. 3.

Rolston, H.I. 1994. Conserving Natural Value. Columbia University Press, New York.

Ross, J.P. and M.A. Barwani. 1982. Review of sea turtles in the Arabian area. In Biology and Conservation of Sea Turtles. Bjorndal, K.A., ed. Smithsonian Institution Press, Washington, DC. $373 \mathrm{pp}$.

Ross, S. and G. Wall. 1999. Ecotourism: towards congruence between theory and practice. Tourism Manage. 20: 123.

Rudloe, J. 1979. Time of the Turtle. E.P. Dutton, New York. 272 pp.

Ruiz, G.A. 1994. Sea turtle nesting population at Playa La Flor, Nicaragua: an olive ridley 'arribada' beach. In Proceedings of the 14th Annual Symposium on Sea Turtle Biology and Conservation. Bjorndal, K.A. et al., eds. NOAA Technical Memorandum NMFSSEFSC-351. 129 pp.

Schofield, G., K. Katselidis, and S. Hoff. 2001. Eastern Mediterranean 'holiday hotspots' versus sea turtle 'nesting hotspots'. Mar. Turtle Newsl. 92: 12.

Schulz, J.P. 1975. Sea Turtles Nesting in Surinam. Rijksmuseum van Natuurlijke Historie, Leiden, The Netherlands.

Seppälä, P. and A. Vainio-Mattila. 1998. Navigating Culture: A Road Map to Culture and Development. Ministry of Foreign Affairs, Department of International Development Cooperation. Helsinki. 60 pp. 
Siakor, S.K. et al. 2000. Liberia sea turtle project. Mar. Turtle Newsl. 88: 9.

Silas, E.G. and M. Rajagopalan. 1984. Recovery programme for olive ridley, Lepidochelys olivacea (Eschscholtz, 1829), along Madras Coast. In Sea Turtle Research and Conservation. Bulletin 35. Central Marine Fisheries Research Institute, Cochin, India. p. 9.

Smith, C. 2002. Valuing and Volunteering for Wildlife Conservation in Tortuguero, Costa Rica. M.A. thesis, University of Western Ontario, London, ON.

Smith, D.V.R. 1983. Palauan Social Structure. Rutgers University Press, New Brunswick, NJ. 348 pp.

Songorwa, A.N. 1999. Community-based wildlife management (CWM) in Tanzania: are the communities interested? World Dev. 27: 2061.

Spring, C.S. 1995. Subsistence hunting of marine turtles in Papua New Guinea. In Biology and Conservation of Sea Turtles, revised edition, Bjorndal, K., ed. Smithsonian Institution Press, Washington, DC.

Suarez, M. and C.H. Starbird. 1996. Subsistence hunting of leatherbacks in the Kei Islands, Indonesia. In Proceedings of the 15th Annual Symposium on Marine Turtle Biology and Conservation. $314 \mathrm{pp}$.

Taft, C. 1999. Lawsuit bans sea turtle killing in Costa Rica. Velador Spring: 2.

Thorbjarnarson, J. et al. 2000a. Human use of turtles: a worldwide perspective. In Turtle Conservation. Klemens, M.W., ed. Smithsonian Institution Press, Washington, DC. p. 33.

Thorbjarnarson, J.B., S.G. Platt, and S.T. Khaing. 2000b. Sea turtles in Myanmar: past and present. Mar. Turtle Newsl. 88: 10.

Thuoc, P. et al. 2001. Training workshop on marine turtle research and conservation in Viet Nam. Mar. Turtle Newsl. 94: 14.

Tomás, J., J. Castroviejo, and J.A. Raga. 1999. Sea turtles in the south of Bioko Island (Equatorial Guinea). Mar. Turtle Newsl. 84: 4.

Venizelos, L. and M.A. Nada. 2000. Exploitation of loggerhead and green turtles in Egypt: good news? Mar. Turtle Newsl. 87: 12.

Wells, M. and B. Brandon. 1992. People and Parks: Linking Protected Area Management with Local Communities. IBRD, Washington, DC.

Wells, M.P. and K.E. Brandon. 1993. The principles and practice of buffer zones and local participation in biodiversity conservation. Ambio 22: 57.

Western, D. and M.A. Wright. 1994. The background to community-based conservation. In Natural Connections: Perspectives in Community-Based Conservation. Western, D. and M.A. Wright, eds. Island Press, Washington, DC.

Williams, R. 1981. Culture. Fontana Press, Glasgow. 248 pp.

Williams, R. 1983. Keywords: A Vocabulary of Culture and Society. Fontana Press, Glasgow. $341 \mathrm{pp}$.

Wilson, C. and C. Tisdell. 2001. Sea turtles as a non-consumptive tourism resource especially in Australia. Tourism Manage. 22: 279.

World Society for the Protection of Animals (WSPA). 1997. Turtle Alert! How the World's Biggest Industry Can Help Save One of the World's Oldest Species. WSPA, London. $10 \mathrm{pp}$.

Yerli, S.V. and A.F Canbolat. 1998. Results of a 1996 survey of Chelonia in Turkey. Mar. Turtle Newsl. 79: 9.

Yuen, E., G. Katsiaficas, and D.B. Rose. 2001. The Battle of Seattle: The New Challenge to Capitalist Globalization. Soft Skull Press, New York. 393 pp. 

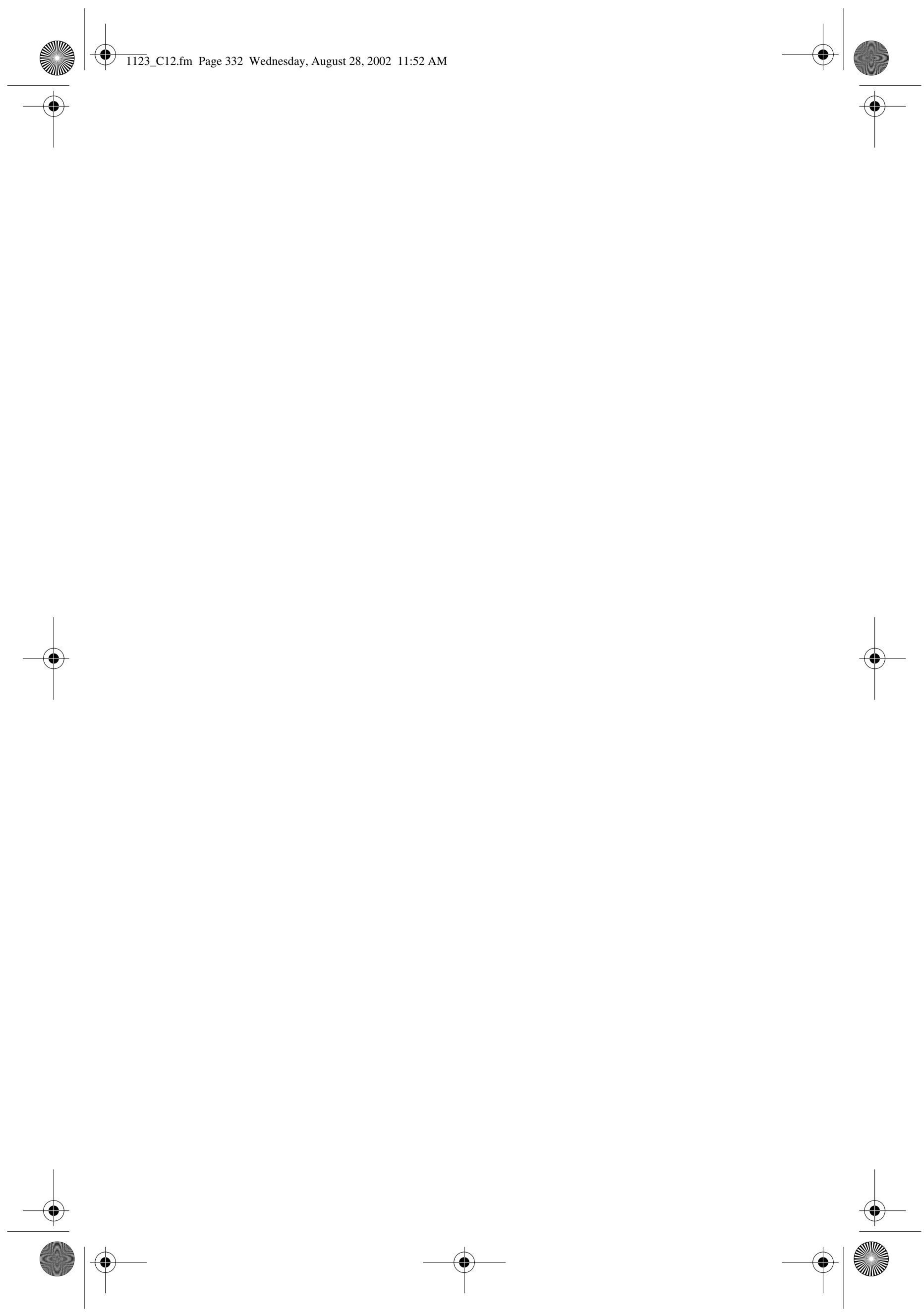